Portland State University

PDXScholar

6-7-1993

\title{
The Assimilation and Integration Processes: A Study of the Commitment Patterns During Students' Entry into College
}

Suzanne M. Pastori

Portland State University

Follow this and additional works at: https://pdxscholar.library.pdx.edu/open_access_etds

Part of the Speech and Rhetorical Studies Commons

Let us know how access to this document benefits you.

Recommended Citation

Pastori, Suzanne M., "The Assimilation and Integration Processes: A Study of the Commitment Patterns During Students' Entry into College" (1993). Dissertations and Theses. Paper 4693.

https://doi.org/10.15760/etd.6577

This Thesis is brought to you for free and open access. It has been accepted for inclusion in Dissertations and Theses by an authorized administrator of PDXScholar. Please contact us if we can make this document more accessible: pdxscholar@pdx.edu. 
AN ABSTRACT OF THE THESIS OF Suzanne M. Pastori for the Master of Science in Speech Communication presented June 7, 1993.

Title: The Assimilation and Integration Processes: A Study of the Commitment Patterns During Students' Entry Into College.

APPROVED BY THE MEMBERS OF THE THESIS COMMITTEE:

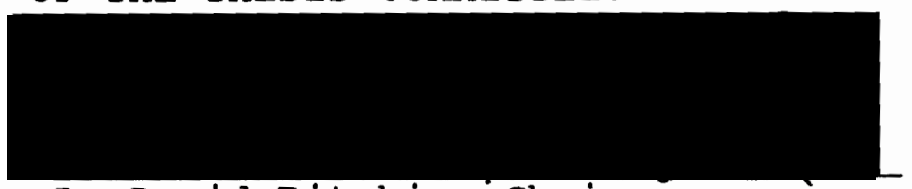

L. David Ritchie, Chair
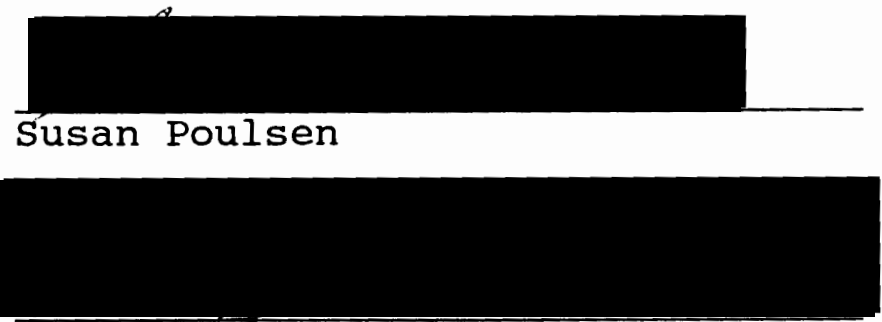

Mary K. Kinnick

This study examined the heuristic value of applying the organizational model of Jablin, Putnam, Roberts, and Porter (1987), who studied newcoming employees assimilating into an organization, to the study of newcoming students integrating into an educational institution.

Three hundred and fifty-five college students were surveyed. I used an adapted version of Mowday, Porter, and Steer's (1982) Organizational Commitment Questionnaire. 
Two hypotheses were tested. Hypothesis one states: The higher the level of expressed commitment the more likely it is that the student will express the intention to remain. Hypothesis Two states: Within Terms one, Two, and Three, the higher the level of expressed commitment, the more likely it is that the student will express an intention to remain. A Pearson Correlation test revealed no significant correlation between commitment and intent to remain for either hypotheses. The high percentage of the subjects who reported that they were 80 to 100 percent certain that they intended to remain and receive their degree yet whose commitment levels were low, suggest that personal goal commitment to receiving their degree is stronger than commitment to the institution.

Commitment to the institution was not supported. Therefore, it was determined that the organizational model had little heuristic value in leading to a clearer understanding of the integration process of college students. However, the survey was distributed to students attending an urban university. This element alone may be a mitigating factor in students' institutional commitment. 
THE ASSIMILATION AND INTEGRATION PROCESSES: A STUDY OF

THE COMMITMENT PATTERNS DURING STUDENTS' ENTRY INTO COLLEGE

by

SUZANNE M. PASTORI

A thesis submitted in partial fulfillment of the requirements for the degree of

\author{
MASTER OF SCIENCE \\ in \\ SPEECH COMMUNICATION
}

Portland State University

1993 
TO THE OFFICE OF GRADUATE STUDIES:

The members of the Committee approve the thesis of Suzanne M. Pastori presented June 7, 1993.
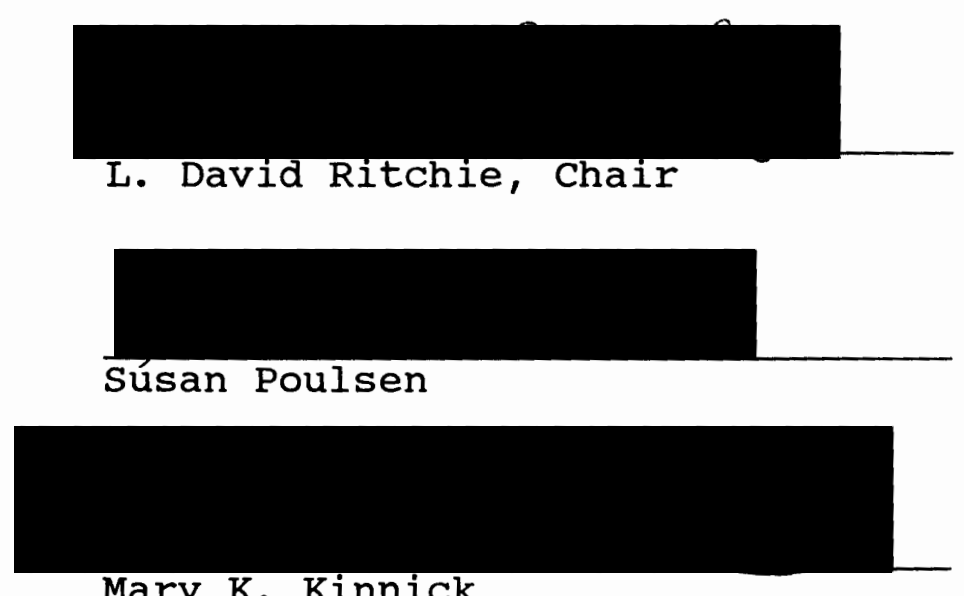

Mary K. Kinnick

APPROVED:

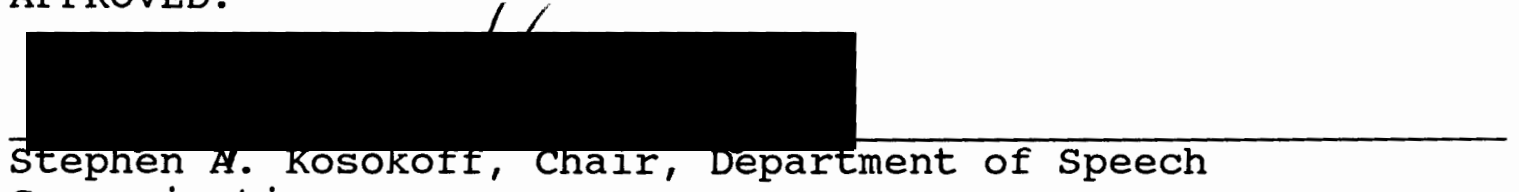
Communication

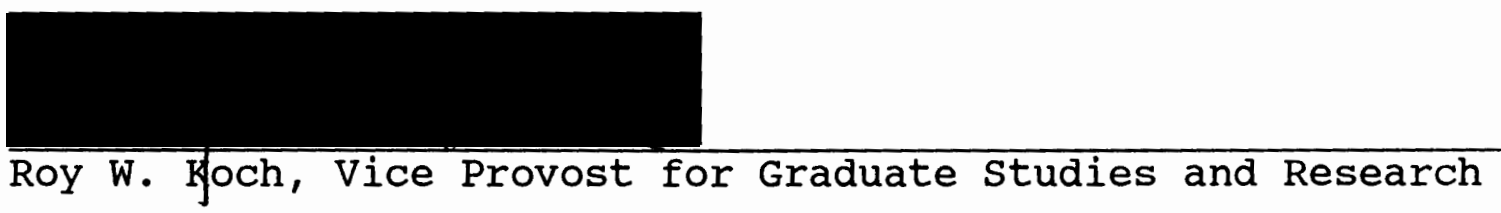




\section{ACKNOWLEDGEMENTS}

To my husband Fred, thanks a million for understanding my need to venture out on my own and supporting me in my "rite of passage." Your steadfast love and devotion enabled me to reach for my dreams and "be all that I could be."

To my Mom, thanks for your unfailing support and tender loving care. Knowing you were keeping the home fires burning gave me peace of mind.

Thanks to my children, Penny, Gina, and Mike for being my cheering squad. Your positive support, humor, love, and encouragement in my darkest moments helped me over the emotional barriers which arose while I was tackling this project. To my adorable angel, Karina, thank you for lifting my spirits with your kisses and hugs. "Grammy" loves you.

To my dear friends, Sue and Ken, Dianne and Jack, Lynn, Steve, and Nanna, thanks for your fabulous dinners and companionship. When I needed a break you were always there to provide fun and helpful advice.

A special thanks to John McKean for the statistical advice; to Trish Smith for the editing expertise; and to Dr. Steers, for your interest in my thesis topic and your colleagues' marvelous questionnaire. 
Finally, thanks so much to you, Dr. Ritchie and Dr. Poulsen, for your expertise. It was an interesting process. I can now move on to my most exciting challenge of all, my teaching career. I've finally found my nitche. 
TABLE OF CONTENTS

PAGE

ACKNOWLEDGMENTS . . . . . . . . . . . . . . . . iii

LIST OF TABLES. • . • . . . . • . . . . . . . . • viii

IIST OF FIGURES . . . . . . . . . . . . . . . . . . ix

CHAPTER

I INTRODUCTION . . . . . . . . . . . . . . I

Rationale. . . . . . . . . . 4

Justification . . . . . . . . . 5

Significance . . . . . . . . . 6

II THEORETICAL BACKGROUND. • • . • • • . • • 8

Organizational Assimilation Theory

Background . . . . . . . . . 8

Assimilation

Assimilation stages

Socialization

Commitment

Organiational considerations and

Limitations

Identification

Educational student Integration Theory

Background . . . . . . . . . .22

Institutional Integration

Pre-Entry Attributes

Institutional Experiences

Personal/Normative Integration

Stage

Goals and Commitment 
The Organizational vs The Academic Model: Their Similarities and

Differences . . . . . . . . . . . 38

Hypotheses. . . . . . . . . . 46

Research Question . . . . . . . . 41

III METHODS. . . . . . . . . . . . . 48

subjects. . . . . . . . . . . . 48

Sample. . . . . . . . . . . . 48

Instrument. . . . . . . . . . 51

Commitment

Satisfaction

Analysis . . . . . . . . . . . 54

Adaptations

Content Analysis. . . . . . . . . 59

Analysis Method

Commitment Scale Limitations

Procedures . . . . . . . . . . 62

Distribution

IV RESULTS . . . . . . . . . . . . . . 64

Demographics . . . . . . . . . 64

Scale Reliability . . . . . . . 66

Hypotheses Tests. . . . . . . 66

Hypotheses. . . . . . . . . . 71

Research Question . . . . . . . 78

Summary . . • . . . . . . . . 80

Suggestions for Future Research . . . 82

Future Implications . . . . . . . 84 
REFERENCES • • • • • • • • • • • • • . . . . 87

APPENDICES

A CONSENT FORM . . . . . . . . . . . . 95

B QUESTIONNAIRE. • . . . . . . . . . . . . 97

C RESPONSE AVERAGES FROM 355 SURVEYS (HI)

AND TERM 1 - TERM 2 - TERM 3 (H2). . . . 105 


\section{LIST OF TABLES}

TABLE

PAGE

I OCQ Commitment Questions . . . . . . . 55

II Section II Satisfaction Questions. . . . 56

III Section I Intentions To Return or Not To Return and Reasons for Planning To Return or Not To Return . . . . . . . . . 56

IV Section II Percentage of Intention To Remain... . . . . . . . . . 57

$\mathrm{V}$ Section II Diversity Questions . . . . . 58

VI Section II Student Survival Question . . . 58

VII Survey Demographics and Demographics From Fall Fact Book, 1992 . . . . . . . . 65

VIII Categories of Open-Ended Question \# 20 Explain Your Reasons for Returning or Not Returning. . . . . . . . . . . 68 


\section{LIST OF FIGURES}

FIGURE

PAGE

1. The Organizational Assimilation Model

(Jablin et al, 1987, p. 695) . . . . . . 9

2. Student Withdrawal Model

(Tinto, 1975, p. 95) . . . . . . . . . 24 


\section{CHAPTER I}

\section{INTRODUCTION}

It is recognized that a college education is not only of intrinsic value to the graduate but also of extrinsic importance in being considered for positions in many professions. Professions such as law and medicine demand a college diploma. However, the number of students who remain with their same college or university from their first encounter to completion of their two or four year program is declining; "more students leave their college or university prior to degree completion than stay" (Tinto, 1987, p. 1). Tinto (1987) predicts that nationally, total enrollment in higher education will continue to decline well into 1995. Whether a college is a smaller, tuition-driven institution or a large, prestigious university, effective budgetary planning is a concern (Tinto, 1975). Retention of students is important, but it is not necessarily the only issue. The quality of education, as well as the social and academic development of the student, is also essential (Tinto, 1987). Tinto (1987) believes that the secret to enhancing student growth, and successfully retaining students through graduation, is embedded in the link between the institution's commitment to the student and the 
student's commitment to the institution. Commitment, according to Mowday, Porter, and steers (1982) is an integral part of an individual's membership status and quality of membership within the organization in which they are employed. Commitment is the "strength of an individual's identification with and involvement in a particular organization" (Mowday et al, 1982, p. 27) .

Commitment is an element in the students' relational development between individuals and institutions (Bean 1980; Pascarella, Duby, Miller, \& Rasher, 1981; and Tinto, 1987), and is viewed as an important component in the relational development between individuals and organizations (Angle \& Perry, 1981; Jablin, 1982 \& 1984; Porter \& Steers, 1973; and Porter, Steers, Mowday, \& Boulian, 1974). Problems that may arise, if employees lack commitment to their organization are increased absenteeism (Covner, 1950), decisions to not fully participate (Morris \& Sherman, 1981), and decisions to leave and eventually withdraw, which is referred to as turnover (Steers \& Mowday, 1981). Individuals make decisions to become committed, participating organizational members or not, and to remain with the work organization or leave (Mowday, Porter, \& Steers, 1982). Likewise, students also make decisions to become committed, participating institutional members or not, and to remain with the institution or leave (Tinto, 1987). 
Tinto (1987) states that commitment can include the students' personal goal of receiving degrees so as to gain employment, and their commitment to the institution in which they are enrolled. Students may also have personal goals of seeking intellectual stimulation, discipline, and socialization into the intellectual tradition. However, students who are more committed to graduating from a certain institution are more likely to graduate from that particular college than are those who are not connected to a specific institution (Terenzini, Lorang, \& Pascarella, 1981).

There can be many reasons for voluntary departure from an institution of higher learning. Students may decide to leave because they feel the courses are too easy or too rigorous. They may be dissatisfied with unrewarding interactions with faculty, staff, and peers, or necessary courses may have been eliminated from the program in which they are enrolled (Tinto, 1987). External environments also play a role in students' quests for higher education.

Personal struggles may arise from escalating financial burdens and difficulties with jobs and families (Bean \& Metzner, 1985).

Thus, departure from an institution reflects the degree of impact both internal and external social and academic experiences have on students' levels of integration into college life. The more positive students perceive these experiences to be, the more likely they will integrate into 
college life and persist until they receive their degree. In turn, the stronger the efforts of the institution to integrate students into both the academic and social aspects of the college experience, the more likely the student will decide to remain (Tinto, 1987).

Bean (1983) determined that student attrition or withdrawal was similar to organizational turnover. Bean also (1980) found that students leave higher education institutions for reasons comparable to those for which employees leave work organizations.

An employee's degree of assimilation into a new work environment appears to be similar to a student's degree of integration into a new academic environment. Therefore, the same principles of remaining or leaving might be applied to the student-university connection in the educational institution.

\section{RATIONALE}

This study will examine the heuristic value of applying the organizational model of Jablin, Putnam, Roberts, and Porter (1987), who studied newcoming employees assimilating into an organization, to the study of newcoming students integrating into an educational institution. The educational model of Vincent Tinto (1987) has been used to promote a clearer understanding of the process of students integrating into institutions of higher education. Both 
models will be compared and contrasted to determine the relevance of using an organizational communication model to study students enrolled in institutions of higher education.

\section{JUSTIFICATION}

Research in the speech communication discipline includes the examination of pedagogical issues on the micro level within the classroom setting yet does not address individuals' commitment levels within the context of a university (institutional) setting at the macro level.

There has been little or no application of Mowday, Porter, and steers' (1982) organizational commitment questionnaire to understanding commitment within higher education systems. There has been no comparison done at the conceptual level between the educational model of Tinto (1987) and the organizational model of Jablin et al (1987).

This thesis will use the model of Jablin et al (1987) to study student integration into the college environment to determine the utility of using an organizational communication model to study students enrolled in institutions of higher learning. When studying student attitudinal and behavioral phenomena, it may be helpful for researchers to draw upon models from various disciplines to assist in broadening the view from different perspectives. 


\section{SIGNIFICANCE}

The patterns which this research identifies may provide useful information to college administrations in tracking student integration. This process may then be seen more clearly in relation to students' decisions to remain or withdraw.

In the study of students and their relational development with an institution, only a few of the organizational models originally used to study employee turnover issues have also been used to study student departure issues. These studies attempted to understand students' attitudes and behaviors which lead to their decisions to persist and remain or drop out and leave their institutions.

In this thesis the applicability of using an organizational model to gain an understanding of the college student-institution connection is examined. Commitment patterns of newcoming students during their first, second, and third terms are also measured. Thus, the information found in this study may provide a more complete explanation of the progression of the students' integration process into their college environment.

According to Mowday, Porter, and Steers (1982), society could benefit when linkages between employees and organizations are strong, which could increase productivity and lead to better quality goods and services. In turn, 
academic communities could also benefit when linkages between students and institutions are strong, which could improve education and lead to better prepared graduates entering their chosen professions. More specifically, if students' commitment to their institution from which they receive their degree are stronger, they may be more likely to financially support their alma mater with alumni donations which could augment funding for scholarship and building funds.

Therefore, the above considerations lead to the following question: Can the organizational assimilation model contribute to understanding the pattern of new student commitment through the encounter stage of integration into an educational institution? 


\section{CHAPTER II}

THEORETICAL BACKGROUND

\section{ORGANIZATIONAL ASSIMILATION THEORY BACKGROUND}

\section{A literature search was conducted of 1 ) the} assimilation process of newcoming employees in an organizational setting and 2) the integration process of newcoming students in an institutional setting.

The assimilation process of newcomers entering into a new organization will be discussed first. The assimilation process includes: 1) socialization, 2) attitudinal and behavioral commitment, 3) the anticipatory socialization stage, 4) the encounter stage, 5) the metamorphosis stage, 6) identification and finally, 7) employee turnover or retention. The theory discussion will be structured around the organizational model of Jablin, Putnam, Roberts, and Porter (1987). The assimilation process is illustrated in Figure 1.

\section{Assimilation}

As individuals move from one community, or environment, to another, whether it involves a workplace, social circle, or educational institution, a process of seeking membership 


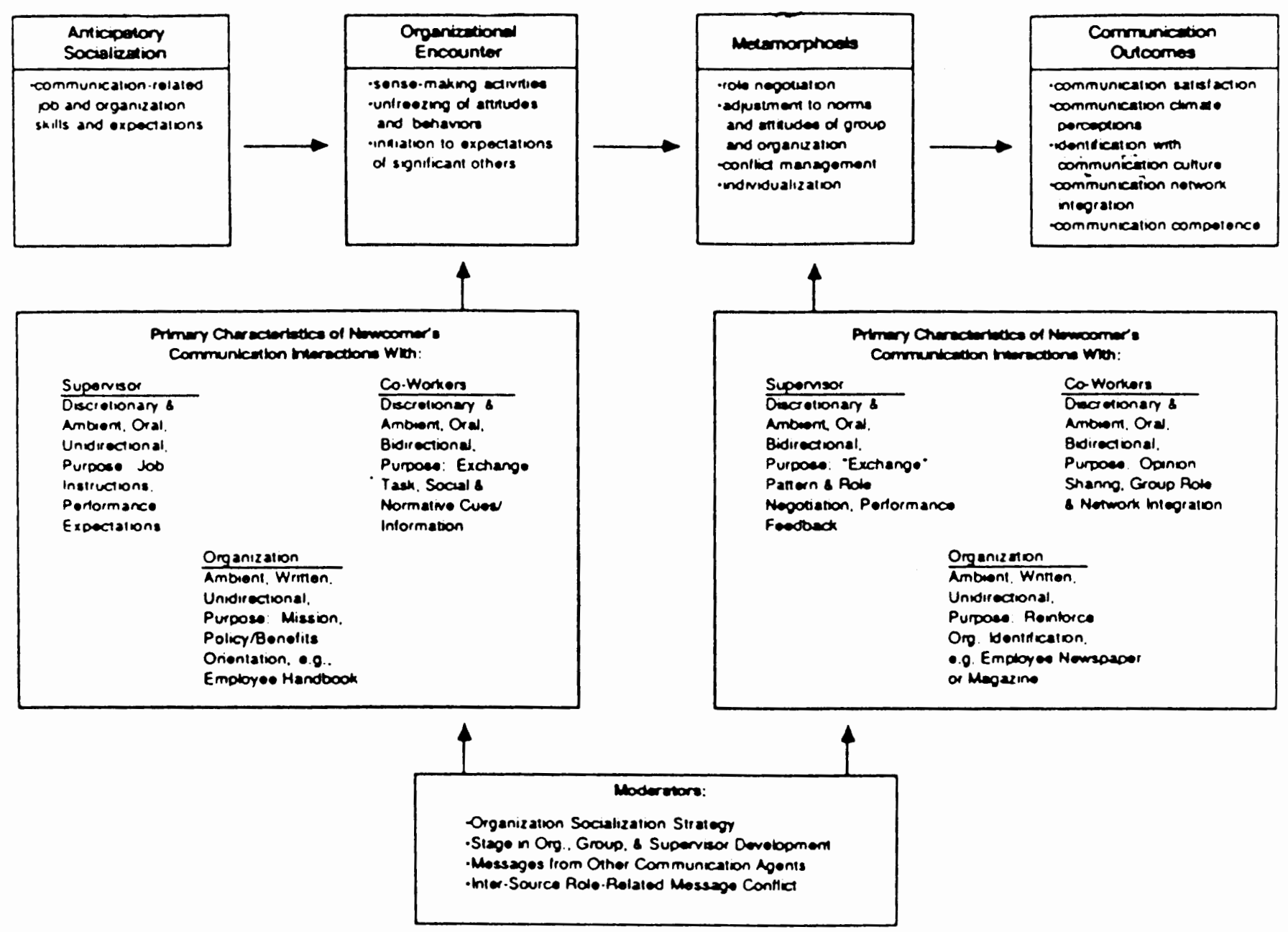

Figure 1. The Organizational Assimilation Model (Jablin et al, 1987, p. 695). 
in the new environment is involved. Becoming a member of a new community involves the assimilation process.

Assimilation is defined by Jablin (1982) as "the process by which organizational members become a part of, or are absorbed into, the culture of an organization" (p. 256). Graen, Orris, \& Johnson (1973) claimed that assimilation of newcomers into the organization takes place during the first few months of employment, the early "entry stage." Jones (1983) suggested the variety of experiences within earlier employment such as the multiple exposures to many different roles, lays the foundation for how the newcomer will react to new situations. A significant factor in facilitating the assimilation process is the realistic expectation level of the newcomer. If newcomers' expectations are too different from their environmental and interpersonal interactions in the new setting, they are less likely to be satisfied with the new situations and organization (Gomersall \& Myers, 1966). When newcomers attempt to establish a unique role identity, they make decisions as to whether new roles fit comfortably into future career plans. If employees perceive little congruence between their new role and their future goals, they are more likely to evaluate their new organization negatively (Jablin, 1984).

\section{Assimilation stages}

For newcomers to feel as if they belong in their new organization, new institution, or new environment, they go 
through a process which may or may not lead to their transformation from an out-member to a participating ingroup member. During the transformation process, newcomers must first relinquish old values, beliefs, and behaviors associated with previous experiences (Van Maanen, 1975).

Any process involves ongoing activity; process is not static. However, it is often difficult to pinpoint a specific event or interaction that signals when and how the newcomer becomes a committed organizational member. In an attempt to organize the study of commitment within the assimilation process, scholars such as Feldman (1976), Schein (1971), and Van Maanen (1975) used stage or phase models to conceptualize the assimilation and socialization processes.

Research in organizational communication suggests that there are ordered, sequential stages through which new employees progress while involved in becoming organizational members (Feldman, 1976). Porter, Lawler, and Hackman (1975) contended that the socialization process, which is included in the assimilation process, contained three phases. Van Maanen (1975) also identified several phases through which new recruits progress during the assimilation process. Jablin et al (1987) consolidated the previous researchers' conceptualizations of stage and phase progressions into three primary stages: (1) anticipatory socialization; encounter; and (3) metamorphosis. According to this model, 
outcomes include identification with the organizational culture, effective perceptions of the organization's climate, network integration, communication competence, and satisfaction.

For clarity and continuity, I will refer to the increments of employee assimilation and student integration as "stages." The three main stages of the organizational model of Jablin et al (1987) will now be described.

Anticipatory Socialization/Pre Entry stage. New organizational recruits come to their new careers with certain expectations as to the characteristics their new occupation and work environment may hold. Expectations are formed through the socialization process beginning in early childhood (Jablin, 1987).

Therefore, the family plays an important role in forming an individual's expectations about organizational life. Information is gathered from parents, peers, friends, teachers, previous jobs, and media. (Crites, 1969). Individuals learn from these sources which college and career to select, and how to communicate, behave, and relate in school and work life (Jablin, 1985).

An influencial factor in the anticipatory stage is the manner in which the newcomer is recruited (Wanous, 1977). If the organization's interviewer imparts unrealistic information about the organization and its environment, and the actual first few months in the new organization are 
perceived by the newcomer to be inconsistent with those earlier statements and previous expectations, the newcomer experiences a lower level of satisfaction and is more likely to leave (Porter \& Steers, 1973). Thus, a significant factor in facilitating the assimilation process is a realistic expectation level of the entrant. If the newcomer's expectations are too different from the actual encounters in the new setting regardless of the reason, the newcomer is less likely to be satisfied with the new situation and organization (Gomersall \& Myers, 1966).

Encounter stage. The first few months of an individual's entry into the new organization are critical in forming a solid foundation for the newcomer. This time is essential for administrators to nurture healthy attitude patterns so that the newcomers and their attitudes will mesh with the organization's policies, values, and goals (Herzberg, Mausner, Peterson, \& Capwell, 1957).

Berlew and Hall (1966) claimed that this stage contains experiences in which the organization reveals its expectations of the newcomers. Schein (1968) argued that when newcomers interacted with seasoned managers and other employees, they absorbed the intricacies of their new surroundings. Dunnette, Avery, and Banas (1973) warned of potential disaster during this early stage, suggesting that this stage is a critical period for the organization to reinforce their policies in the newcomer's day-to-day 
experiences. Gomersall and Myers (1966) declared that this time is for new employees to let go of the expectations and behaviors that do not match with their organizations' cultures.

To foster full participation, the individual may be asked to attend an orientation program (Louis, Posner, \& Powell, 1983), which usually takes place in the early stages of the recruit's entry into the organization. During the "breaking-in" period, as Van Maanen (1975) calls it, orientation sessions enable an individual to get in step with the organization: "Orientation helps a person adapt to a particular situation by establishing and sorting out relationships within his or her new environment" (Wehrenberg, 1989, p. 6).

When individuals interact with strangers during their initial encounter within the context of their new surroundings in the organization, uncertainty may develop on how to behave (Berger \& Calabrese, 1975). In the individual's sense making process of deciphering new roles, new rules, and behaviors, uncertainty levels may increase. In turn, stress levels may also increase. Therefore, stressful circumstances can push an individual toward a decision to not participate whole-heartedly in the assimilation process within the organization (March \& Simon, 1958). 
Establishing relationships between newcomer and organization during this stage is critical. These relationships may produce a long-lasting positive effect on the newcomer (Katz, 1980). Leadership skill deficiencies and insensitivity towards subordinate's needs can increase the newcomer's uncertainty level (Dunnette, Avery, \& Banas, 1973), because during the encounter stage, the newcomers seek information to help clarify their role identity and expected behaviors so as to reduce uncertainty.

Confusing or conflicting information can lead to high anxiety. To reduce psychological stress, newcomers may reduce their frequency of communication with others (Kahn, Wolf, Quinn, Snoek, \& Rosenthal, 1964). In an educational institution, for example, a new student may reduce the frequency of communication with a professor or peer to reduce psychological stress. This reduced interaction may slow the newcomer's transformation into a participating member of the new organization.

Metamorphosis stage. The third stage, metamorphosis, refers to the stage during which the newcomer is more likely to change from an out-member to an inside participating member (Jablin et al, 1987). The individual adjusts previous behaviors, attitudes, and values to be more congruent with those of the new organization. The metamorphosis period may be the stage wherein true identity with the organization takes place, and may occur over the 
first few years of organizational tenure (Jablin et al, 1987). When newcomers are changed into integral, participating, identified, committed members, the process is deemed a success (Jablin, 1986).

\section{Socialization}

Organizations bring newcomers on-board through socialization practices in order to peak newcomers'interest in different facets of the organization as well as to create a stronger bond with the organization. Socialization practices such as orientation programs, employee development and training sessions, company picnics or parties help employees assimilate into their new surroundings (Mowday et al, 1982). Schein (1968) defines socialization as, "the process of learning the ropes, of being indoctrinated and trained, of being taught what is important in an organization" (p. 2). Van Maanen (1975) stated that organizational socialization is, "the process by which a person learns the values, norms and required behaviors which permit him to participate as a member of the organization" (p. 67). Feldman (1976) stated that, "globally, organizational socialization is the process by which employees are transformed from organization outsiders to participating and effective members" (p. 23).

Finally, Jablin et al (1987) referred to socialization as two reciprocal dimensions: an organization tries to influence individuals (socialization) and individuals try to 
influence the organization so as to individualize their roles in the organization (Jablin, 1985).

Information can be distributed to a newcomer by formal and informal socialization strategies. The formal process may consist of orientation programs, which usually include information about rules, policies, and goals (Van Maanen \& Schein, 1979). In the college setting an institution might hold an orientation program each fall for Freshman and other incoming students. The informal process may involve social interaction, such as interaction with professors and peers, during which stories are told which reveal the organization's and members' expectations, values, norms, and rules (Brown, 1985).

\section{Commitment}

Another element in the assimilation process is commitment, which is considered to be an ongoing process (Mowday et al, 1982), and has been conceptualized in a number of ways. Commitment within the assimilation process and its interrelated constructs can be viewed as: a) a part of the assimilation process and as b) an outcome of the process. In particular, commitment is both attitudinal and behavioral (Mowday et al, 1982).

Attitudinal Commitment. Mowday, Porter, and steers (1982) defined attitudinal commitment as,

the relative strength of an individual's identification with and involvement in a particular organization characterized by at 
three factors, involving (a) a strong belief in and acceptance of organizational goals and values; (b) a willingness to exert considerable energy on behalf of the organization; and (c) a strong desire to maintain membership in the organization (p. 43).

Mowday et al (1982) also maintain that a reciprocal relationship exists between attitudinal commitment and commiting behaviors such as remaining or leaving. Morrow (1983) defined attitudinal commitment as the "devotion and loyalty to one's employing firm (p. 320)."

Behavioral commitment. The study of behavioral commitment dates back to Becker's (1960) study in which he described commitment as a "side-bet" concept which refers to an employee's accrued benefits with the organization ( $p$. 22). An individual may decide to continue with an organization because of the benefits, which may be perceived as rewards.

steers (1977) found that when individuals assimilate into a new organization, they bring with them the need for achievement: to successfully fulfill their job role or their personal goals. They decide to remain with the organization if their role furnishes them with opportunities to fulfill that need. students may also bring to their college experience a need for achievement. Students may perceive achievement as earning acceptable grades, successfully interacting with professors and co-students, and receiving a degree. Students may also perceive achievement as understanding complex ideas, learning problem-solving 
understanding complex ideas, learning problem-solving techniques, effectively working in groups, and increasing their knowledge in a variety of subject areas. Therefore, a student's achievements may be seen as rewards and influence their staying (Spady, 1970).

Social exchange theory researchers Thibaut and Kelley (1959), in their studies of interpersonal effectiveness, maintain that, "we develop relationships in which our rewards will be greater than our costs" (p. 107). They (1959) asserted that an interdependence exists between costs and rewards. If students have perceptions that their university is a source of high rewards and low costs, the attractiveness of interacting with the faculty, peers, and administrators increases. Conversely, if students' perceptions that the university is a source of high costs and low rewards the likelihood increases that they will decide to withdraw in favor of alternative institutions. However, difficulty arises in defining that which constitutes a cost and that which constitutes a reward.

\section{organizational Considerations and Limitations}

The nature of the organization is an important factor in studying commitment issues, since the organization seems to be the locus of the individual's commitment. organizations exist to further the goals of more than one group. There are multiple goals of the employees, the 
customers, the management, the company as a whole, and the general public (Reichers, 1985).

within organizations, many types of relationships take place. These relationships evolve within various groups. Employees as well as students interact with various reference groups, defined as "Those groups with whom individuals identify and to whom they refer in making judgments about their own effectiveness (Gouldner, 1957, p. 34). Therefore, the researcher will focus on the perception of the students' commitment to their own goals and their commitment to their institution. Tinto's educational model addresses these two commitments (1987).

Another difficulty that arises according to Reichers (1985) is "Commitment is a process of identification with the goals of an organization's multiple constituencies. These constituencies may include top management, customers, unions, and/or the public at large (p. 465)." Therefore, separating the multitude of commitments and their referents and outcomes is a complex task (whether commitment eminates from the administration, management, or the newcomer). Reichers (1985) also feels that there is a lack of consistency in the definitions of commitment. Therefore, he believes the antecedents of commitment would be correspondingly inconsistent. Reichers also suggests that the following two questions which are purported to evaluate the individual's motivation to maintain organizational 
membership, are similar to intention to stay or leave items, which are said to be predictive of employee turnover:

It would take very little change in my present circumstances to cause me to leave this organization. and

I would accept almost any type of job assignment in order to keep working for this organization (Mowday et al, 1979, p. 288).

It is Reicher's contention that the consistent relationships found between commitment and turnover may be partially false. He suggests that "future conceptualizations of commitment need to separate the construct from its effects (1985, p. 469)."

\section{Identification}

An outcome of employees' identification with their organization is related to the degree of organizational assimilation. Individuals need some shared and common understanding of the culture of the organization. organizational culture informs employees of the organization's values and beliefs. The more employees identify with their organization, the more solid the connection between employee and organization (Pfeffer, 1981).

The component of identification may be linked to an individual's loyalty to the organization in which he is a member; more specifically to identify to the organization's goals (Cheney, 1983). Cheney and Tompkins (1987) conceptualized identification as a process as well as a 
product/outcome of the identifying process. Simon (1976) treated identification as an internal process or feeling which takes place within the employee. On the other hand, Patchen (1970) described identification as a reciprocal process containing shared, supportive elements with group members, loyalty, and a unification of goals and values between employees and their organization.

According to Tompkins and Cheney (1985), "A decisionmaker identifies with the organization when he or she desires to choose the alternative which best promotes the perceived interest of the organization (p. 194).

In summary, this theoretical background has attempted to present an integrated discussion of the assimilation process. Many individuals may experience the process many times in their careers. Assimilation encompasses ongoing processes by which individuals join, learn the intricacies of their new roles, become integrated into, and exit organizations (Jablin, 1982).

\section{EDUCATIONAL STUDENT INTEGRATION THEORY BACKGROUND}

Tinto (1982) developed a theory of student integration and withdrawal which encompasses characteristics and causes of student departure to explain the process of student integration into or departure from institutions of higher education. He produced a model to illustrate the complex 
issues in the institution-student link in the students' social and academic development.

A description of Tinto's (1987) entire educational model may provide the reader with a more complete, in-depth picture. It contains three components: 1) pre-entry attributes; 2) formal and informal institutional experiences; and 3) personal/normative integration. The student's goals and commitments are intertwined within the integration process. The theory discussion will be organized around Tinto's (1975) educational model of the student integration and withdrawal process depicted in Figure 2.

Tinto defined integration as, "some type of social and/or intellectual membership" (1987, p. 121). He proposed that integration includes two forms; social and intellectual, and that both forms of experiences are necessary for the complete development of the individual. He argued that,

...social and academic experiences continually act upon individuals' evaluation of their educational and occupational goals and their commitments both to the attainment of those goals and to the institution into which initial entry has been gained. Integrative experiences heighten the likelihood of persistence. Their absence increases the likelihood of departure by establishing conditions which tend to isolate the individual from the daily life of the institution. In turn, these conditions serve to reduce goals and weaken commitments, especially to the institution (p. 120). 


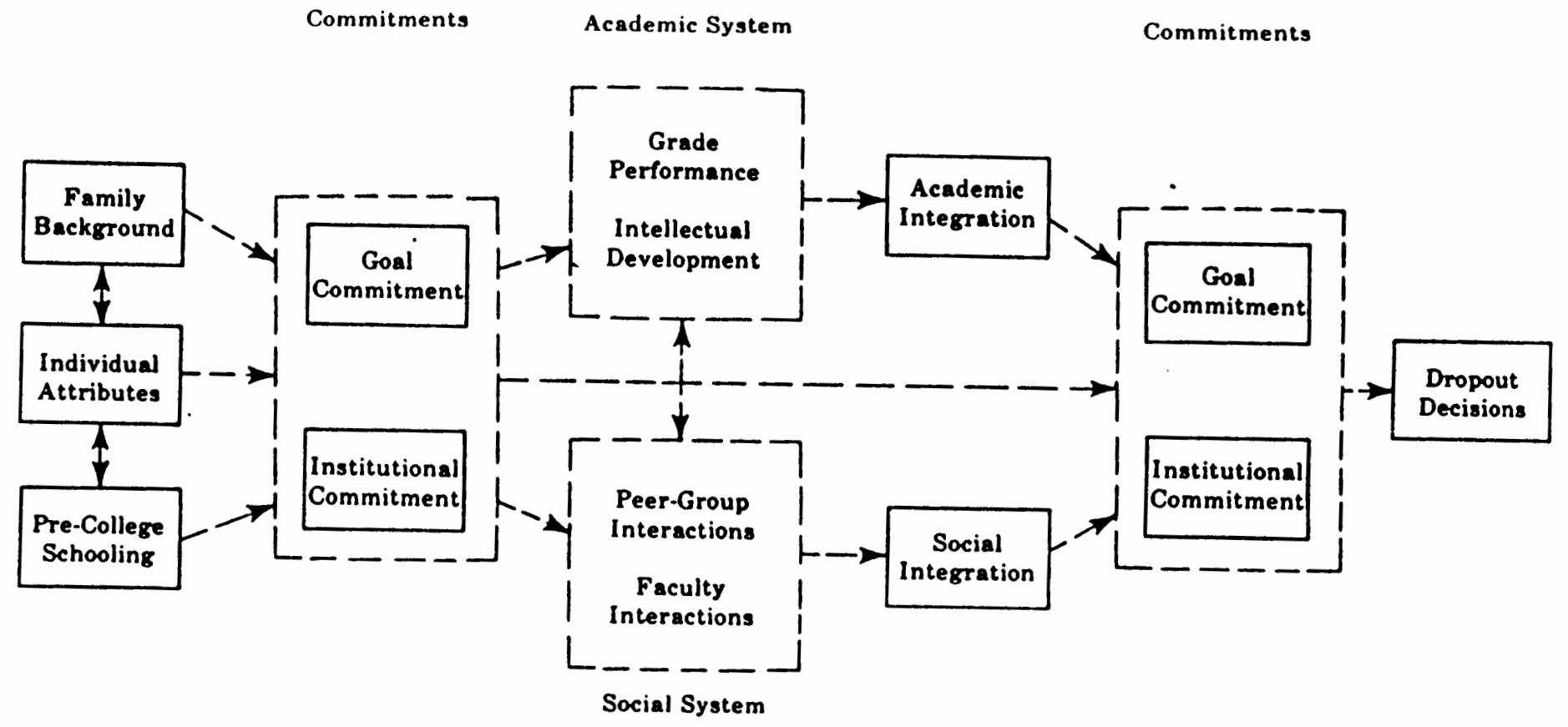

Figure 2. Student Withdrawal Model (Tinto, 1975, p. 95). 
Tinto studied students' levels of commitment in connection with their social and intellectual integration into their university environment and their persistence in getting a degree $(1982,1987)$. Tinto's (1987) model of the integration process of students into the educational community and institution is based on Van Gennep's stages of an individual's process of membership establishment and social integration in various types of societies.

Tinto concluded that college students are more likely to leave college if they are inadequately integrated into their university. He also contended that, if a student's values are significantly different from the values of the college, the student is more likely to withdraw (1987). Tinto also stated that "other things being equal, the higher the degree of integration of the individual into the college systems, the greater will be his commitment to the specific institution and to the goal of college completion (1975, p. 96)."

Spady (1970) also found that college survival depends on students having interests that are compatible with expectations of the university, faculty, and curricula. In general, students who became involved in campus activities and interacted with other students and faculty developed stronger commitments to receiving their college degree (Tinto, 1987). 
Researchers who studied student integration into their college setting and issues of student commitment often used the educational models of Tinto (1975) and Bean (1980). These researchers supported the student social integration propositions of the Tinto (1975) and Bean (1980) models (See Cabrera, Castaneda, Nora, \& Hengstler, 1992; Christie \& Dinham, 1991; and Terenzini et al, 1981).

However, only one organizational model was used to study student integration, which is referred to as the industrial student attrition model (Bean, 1980; Price, 1977). Price's 1977 model was originally used to study employee turnover, within the organizational framework. This model was then adapted to study issues within the educational domain. For example, the variable of grades was substituted for the salary variable. Bean's (1981) study included other variables such as practical value, development, routinization, instrumental communication, participation, integration, courses, distributional justice, campus organizations, opportunity, and marriage. These variables had either a negative or positive effect on satisfaction, which had an effect on the student's intent to leave or remain.

A major portion of Tinto's work in understanding the process of high school student integration was based on statistics drawn from the National Longitudinal Survey (NLS) of 1972 high school graduating students' activities. Tinto 
claimed that the NLS data was the most comprehensive information gathered nationally on students' progress through the higher educational system of college. He studied students' rates of attaining a four-year degree, as well as rates of departure. He examined data from several different types of colleges. Some were large urban colleges, while others were small private universities. In the study of integration, he found that academic integration was more important to men and social integration was more important to women. He also found that students' informal contact with faculty members outside the classroom was important to both men and women, whether they were enrolled in their first year or their senior year. During those contacts students felt it very important to discuss intellectual philosophies and course-related matters. A significant finding was that the best predictor of institutional commitment was social integration (Tinto, 1987). Bean (1985) also found that institutional commitment was a more prevalant factor than institutional fit.

Students' personal commitments, such as receiving their degrees, and their commitment to their university is reciprocal in nature. The institution should not, however, just be interested in trying to retain more students who will ultimately graduate from their university, but be concerned with the quality of students' overall educational 
experience. The institution should take an active role in students' academic and social development (Tinto, 1987).

\section{Institutional Integration}

In the study of student integration, Tinto (1975) called the assimilation process the "rite of passage," which takes place in several contexts. For example, a "rite of passage" may take place when a student moves from a small community college to a large university, a high-school setting to a college campus, or from a parent's home to campus living quarters. Becoming an in-member of the college community is a process that occurs over time, as in the work organization model (Tinto, 1975).

Van Gennep (1960) referred to rites of passage as "the stages in membership integration, which is not the same sequence for everyone, and may be separate or overlap" ( $p$. 98)." He cautioned that these stages are not developed to the same extent by all individuals or in every set of circumstances. However, he contended that if members of a particular group offered welcoming rituals to an individual seeking membership in that group, the likelihood the newcomer would more successfully integrate into that group. If members of a particular group did not incorporate inclusionary rituals as a socialization strategy, individuals seeking membership in that group would be more likely to not persist and withdraw (1960). 
Van Gennep's (1960) study of individuals immersed in life crises has been valuable in understanding how individuals adjust to new circumstances (Tinto, 1987). To pass from group to group an individual must fulfill certain conditions. He contended that no matter what the event, indicative ceremonies exist to help individuals pass from one stage to the other. Van Gennep's "stage" premise involved the study of rites of passage of childhood, adolescence, betrothal, and marriage (1960).

Van Gennep (1960) claimed, however, that the basic process is usually the same whether an individual is passing into marriage or into adolescence. Individuals separate from a primary group or event, then move on into a transitional period, enter the new situation, and become incorporated or not incorporated in the new circumstance.

Tinto based his study of student withdrawal and integration on Durkeim's theory of suicide (1951) and Van Gennep's (1960) theory of departure. Both Durkeim and Van Gennep tackle the issue of reasons individuals voluntarily withdraw from communities. Durkeim (1951) contended that suicide reflected "the breakdown of social and intellectual bonds which tie individuals to each other (p. 45)." Durkheim (1951) argued that suicide arises "when individuals are unable to become integrated and establish membership within the communities of society (p. 50)." Both theories were found to have utility in understanding the complex 
variations in the process of moving in and out of different communities. These theories addressed the human dilemma of being able or unable to become integrated into full membership within a variety of communities within a society (Tinto, 1987).

Separation stage. This stage involves an individual's dissociation from past life circles, and may produce isolation, stress, and a feeling that the new life's event is less rewarding.

Tinto related this stage to the student's separation process from family, high school friends, and teachers, as well as home-town areas of residence. Not only do some students physically separate themselves from old support systems, but, emotionally, they begin to sever connections with old groups (1987).

Transition stage. After separation, this stage occurs between the old and the new situation. An individual has yet to embrace the norms and patterns of the new situation or environment. In such a period of change, an individual may experience a strong feeling of isolation and distress, which could be problematic (Cutrona, 1982). During this stage an individual may feel in limbo, not quite belonging to either group (old or new). A strong motivation to fit in, however, may have an effect on the desire to participate in the new environment, which results in emulating the behaviors of the new community's members (Tinto, 1987). 
Tinto also asserted that the student's transition stage could be more difficult if too great a difference existed between the norms and behaviors affiliated with membership in past communities and those involved in college life (1987).

Incorporation/Integration stage. This stage occurs after the transition stage. In various levels of adaptation (such as the student interacting more often with the professors and peers, attending more campus events, or joining a campus organization) the individuals' old norms, beliefs, and values are exchanged for the new, becoming more united in nature. Integration into the new community begins to take shape (Tinto, 1987).

The integration stage involves some form of inclusionary practice or ritual, which could include eating or drinking with the new group, touching, back slapping, or exchanging gifts. Reciprocity between current members and newcomers plays a key role in the ritual. Finally, incorporation into the new environment causes individuals to identify themselves in some way with the new group members (Van Gennep, 1960).

Tinto (1975) described the integration stage as a time when students learn the ropes, sometimes on their own. He suggested that if students participate in such activities as intramural sports, sorority or fraternity events, dormatory association meetings, or attend lectures and concerts, they 
will be provided with more opportunities to gather more information about college life.

The three components within the integration process of students entering their college life are pre-entry attributes, institutional experiences, and personal or normative integration stage.

\section{Pre-Entry Attributes}

This component consists of the background characteristics which students possess that either help or hinder the success of their college experience. Tinto (1975, 1987) stated that if the student's family were educated in a higher education system, they were more likely to advise the student to enter college. He asserted that this support played an important role in encouraging students to persist in college and attain a degree. Tinto (1975) and Bean (1980) agreed that a student's academic skills and abilities acquired from elementary and high school did not play as important a role as the influence of strong family support.

They also claimed that the students' participation in campus activities and their integration into their new campus environment played a greater role in the students' decisions to remain in college than it did in decisions to withdraw. It also played a role in students' decisions to receive their degree.

However, when students were academically ill-prepared by the high school or college from which they transferred, 
they struggled with their studies and earned lower grades than students more academically prepared (Bean \& Metzner, 1986)

students enroll in college for various reasons. They have different levels of commitment to their personal goals such as a desire to receive more knowledge and skills in a particular field and/or to receive a college degree. Tinto submits that this longitudinal integration process includes the students' personal goal commitments as well as commitment to the institution in which they are enrolled (1975, 1987). If students' experiences are perceived as negative, the likelihood that the students will decide to leave thereby increases (Tinto, 1987).

If the student's experiences are perceived as positive, the student's frequencies of interaction with co-students and institution personnel (such as professors, administrative employees, and support personnel) increase. These behaviors tend to increase the likelihood that the individual will persist and attain the degree. If positive integration is prevelant within the student's college experiences, the student's commitments are strengthened (Tinto, 1975, 1987).

Earlier, in Spady's (1970) study of students' dropout process and students' persistence to remain and receive a degree, he also had suggested that the student's positive interaction with peers and faculty members influences the 
students' assimilation process into the academic and social systems of college. He declared that the student's attitudes, interests, and personality characteristics need to be congruent with the college environment for the student to be successful. If dissimilarity exists, students are less likely to feel compatible with their social system.

\section{Institutional Experiences}

Institutional experiences, according to Tinto (1987), take place within two systems, academic and social. If the experiences are deemed as rewarding, students are positively influenced to remain. The academic and social systems are connected by formal and informal experiences.

Academic system. This system consists of the student's academic performance, which is related to faculty and staff interactions. Each component unavoidably influences events which occur in other parts of the institution (Tinto, 1987). If the student perceives faculty/staff interactions as negative and unrewarding, he or she is more likely to reduce the interactions, which can lower academic performance in the formal system. These interactions takes place in the classroom as well as outside the classroom; That which happens in either place influences the student's intentions to remain or leave (Tinto, 1987).

Formal. The formal domain includes the student's grades, which reflect the student's academic performance. Bean (1980) maintained that the student's 
academic performance was an important variable which influenced commitment. The formal system encompasses the events which occur within the confines of classrooms and laboratories (Tinto, 1987).

Informal. The informal system includes student interaction with the faculty and staff. This contact influences the student's judgments about the level of commitment reflected by representatives of the institution. In turn, the development of the individual's commitment to the institution has an impact on the student's decision to integrate and persist (Tinto, 1987).

social system. The social system consists of events and interactions which occur inside and outside the classroom. Tinto (1987) contended that some degree of integration in both the social and academic systems is necessary for student persistence. He indicated that there is an important interplay between the academic and social elements of student life (1987).

Formal. Extracurricular activites are included in the formal domain of the student's social system. The more involved students become in the campus extracurricular activities, the more likely they will persist (Tinto, 1987). Christie and Dinham (1991) confirmed that student participation in extracurricular activities enhances the students'opportunities for 
integration into the college social system by helping them meet other students and developing friendships. Informal. The student's peer group is included in the informal domain of the student's social system (Tinto, 1975). This peer group is a primary agent of socialization (Bean and Metzner, 1985).

\section{Personal/Normative Integration stage}

This stage includes the intrinsic rewards, such as the feeling of accomplishment by completing difficult courses, of the student's intellectual development (Tinto, 1987), which consists of opportunities for a variety of intellectual stimuli, such as invigorating lectures by professors or visiting speakers and challenging academic rigor. If students view their experiences as rewarding, an increased institutional commitment occurs (Tinto, 1987). Conversely, a contributing factor for student withdrawal can be a student's perception of coursework as too easy or routine. Students who preceive the curriculum to be too easy may not feel challenged to their full intellectual capacity. Also, students who perceive their classes to be too routine may feel a lack of intellectual stimulation (Tinto, 1987).

Academic Integration. In Pascarella, Duby, and Iverson's (1983) study of urban, commuter college settings, they stated that the student's positive academic integration was consistent with Tinto's (1975) academic integration 
model. High levels of academic integration should increase institutional fit, which is the perceived match between the individual's values and the institution's values, as exhibited through behaviors of the college representatives and an important predictor of student dropout (Bean, 1985). Social Integration. Interactions within the social systems of the institution are central to the development of the bonds which help to integrate the individual into the community (Tinto, 1987). The social integration process includes those day-to-day interactions with faculty, staff, and students which occur outside the classroom. A wideranging contact with these people enhances the likelihood of increased commitment, since interpersonal connections help make the student feel a part of the college setting (Tinto, 1987)

\section{Goals and Commitment}

Goals can range from the students' personal goals, such as commitment to attaining a degree in their chosen field, to the commitment to their institution in which they are enrolled (Tinto, 1987). There is a distinction between students' motivation to fulfilling the program requirements which lead to receiving a degree and motivation to receiving an education. Many students attending college are currently employed and hold high status positions, earning excellent salaries. Their goals may be intrinsic in nature such as expanding their knowledge to enrich the positions they 
already hold. Their goals may also be extrinsic in nature such as receiving a second degree to enable them to change careers or open more options for advancement in their current career. Strong commitment to the goal of college completion may lead to an increased likelihood that they will persist in getting the degree, regardless of experiences (Tinto, 1987). A strong interrelationship exists between students' personal goal commitments and their commitment to their institution. The student's personal goal commitments and their commitments to the college are reciprocal in nature. As the student's personal goal commitment increases, the student exhibits increased committing behaviors, which in turn assists in increasing the student's commitment to the institution (Tinto, 1987).

THE ORGANIZATIONAL VS THE ACADEMIC MODEL: THEIR SIMILARITIES AND DIFFERENCES

A comparison and contrast of the organizational model of Jablin et al (1987) and the academic model of Tinto (1987) will be discussed. First I will discuss the broad similarities and differences between the two models. Then I will more specifically address the components in each model. Both models are based on linear, sequentially patterned stages which occur over time, through which the individual passes in his/her integration or assimilation into a new 
environment. However, the organizational model focuses more on individuals' new roles than does the academic model.

Both models include a commitment component. Commitment is a factor throughout the assimilation process in the organizational model. Although Jablin et al (1987) do not specifically have a commitment concept box in their model, commitment is present throughout the encounter, metamorphosis and identification stages. The organizational model is related to job satisfaction and the identification process, and is linked to the degree of employee participation within the assimilation process (Jablin, et al (1987). Organizational commitment is positively related to the degree to which newcomers are integrated or assimilated into their organizational networks (Eisenberg, Monge, \& Miller, 1983; Mowday et al, 1982). The organizational model includes commitment as a positive factor in the newcomer's integration process within organizational communication networks (Buchanan, 1974).

on the other hand, the educational model specifically distinguishes between the students' goal commitments and commitment to their institution. students' goal commitments are related more to their personal commitments to learn and to receive their degree. Their institutional commitment is related to the university as a whole. Students make judgments whether their university provides them with intellectual stimulation, a variety of extracurricular 
activities, and an environment in which to grow academically as well as socially. When they begin to see themselves fitting in and becoming an integral part of the college, they view their commitment to their college more strongly (Tinto, 1987).

Both models refer to the socialization process. The organizational model highlights the organization's attempts to socialize the new employees by informing them of expectations for carrying out and completing job tasks. The organizational supervisors and co-workers, through social interaction, relate organizational behaviors, rules, and norms, and formal orientation. The organization's expectations are revealed during the anticipatory socialization stage and the encounter stage.

The educational model, however, makes a distinction between an individual's (a student) interaction within a social system and an academic system. The social system includes interaction with peers, faculty, administration and support personnel within the informal category. The formal category includes campus extracurricular activities and other activities available for students living on or near campus. The organizational model does not make any distinctions regarding what type of system an employee interacts.

Both models include an individual's decision or intention to remain or leave. However, the educational 
model specifically refers to the final outcome as a decision to withdraw or dropout, while the organizational model refers to the final outcome as turnover. Both offers reasons for departure. Both models, nevertheless, focus on an individual's voluntary decision to leave. Not fully explored in either model is the involuntary departure of employees, such as termination, or a student leaving because of a grade point average below college standards or a serious infraction of a campus rule.

Both models are used to explain attitudes and behaviors either in the workplace or in a postsecondary educational institution. Both models are based on individuals' perceived attitude toward the degree of institutional fit. If individuals feel that there is too great a disparity between their values and the organization's values, they perceive the institutional fit not congruent. Therefore, they tend to be more likely to leave.

Both models acknowledge that individuals bring prior experiences, talents, characteristics or traits into the new environment, which influences the assimilation and integration processes. Individuals are from particular races, practice different religions, display various aptitudes or talents, and have different financial concerns. These factors color individual's perceptions on how they view and interpret their roles and how they make judgments of behaviors of supervisors, co-workers, and administrators 
in an organizational setting. They also go through similar judgments about the behaviors of faculty, peers, and staff in an educational setting.

Both models take into consideration the reciprocal nature between individuals'interaction or participation levels in the new work or school environment and the organization's level of interaction with individuals. On one hand the organization shows interest in the employees' welfare, such as offering a complete benefit package and providing extra job training. Then employees reciprocally become more closely linked to the organization and begin to build more loyalty and devotion. On the other hand, the institution shows interest in the students such as offering high quality, state-of-the-art courses taught by renowned professors and providing intellectually stimulating lectures and a variety of extracurricular events. In turn, reciprocally students become more closely linked to the institution and begin to build more loyalty and devotion.

The models differ in that the motivation or commitment an employee displays is different than the motivation or commitment a student displays. Employees are usually motivated or committed to remain with the organization for a longer period of time. Their expectations are such that they believe the organization will care about them enough to provide opportunities for personal and professional growth, which might elevate them to higher positions. In turn 
individuals would be given more role challenges which would lead eventually to receiving higher salaries. Students are committed to their personal academic and intellectual growth for shorter periods of time within the college setting. However, learning is acknowledged as a lifelong process which takes place not only on a college campus but outside the campus as well. As soon as students receive their degree or finish a particular course, they tend to withdraw and enter the workplace to begin utilizing their knowledge that they acquired during their college experience. However, there are students who decide to remain in college after their undergraduate degree and enroll to receive a higher degree.

Both models depict formal and informal communication communication categories. In the organizational model formal communication consists of brochures, advertisements, policy handbooks, and organizational orientation programs. Informal communication consists of interaction with peers, supervisors or faculty, and management or administrators. These categories are labeled communication networks which relate more to communication informational channels by which information is sent and received. In the educational model, however, the formal and informal systems appear to be domains in which students interact, such as more formally in labratories and classrooms and informally at campus events during extracurricular activities. The educational model 
includes an academic factor: the student's academic performance. The organizational model does not include a specific component which discusses the employee's job performance.

Both models are indirectly based on individuals' judgments of their experiences. Individuals label an experience as a reward or a cost. If they judge their experiences positively, they are more likely to remain. If individuals judge the experiences negatively, they are more likely to leave. Therefore, both models are based on a cost/reward ratio.

In an analysis of the individual stages in each model there are some basic differences. The underpinnings of Tinto's $(1975,1987)$ educational model is based on Van Gennep's (1960) stages of an individual's process of membership establishment and social integration in various types of societies. These stages are the underlying philosophy of the integration process and are not explicitly listed in the actual education model. The organizational model explicitly lists three distinct stages in the assimilation process, which are: anticipatory socialization, encounter, and metamorphosis (Jablin et al, 1987).

Both models include individuals' expectations of what their new organization or new institution will hold for them as they enter their new environment. The organizational model calls the first stage the Anticipatory Socialization 
Stage, which includes the individuals' expectations of the traits their new job and work environment may hold. The educational model calls the first stage the Pre-Entry Attributes. This label, I believe is misleading since its title appears to address only the students' traits and characteristics present before entry into college. However, in the discussion of those attributes, family background, and prior academic experiences, students' expectations are indirectly addressed. Students' expectations of what college will entail are based on their elementary and secondary school experiences. The expectations of family members also influence students' expectations of their postsecondary education. Families discuss what their current career positions entail, which influence the students' decisions on course and program selection. The similarity exists in that these expectations can be based on events they have heard others talk about or events that they personally experienced. This information gathered from the beginning of early childhood and continues throughout the students' college experience (Tinto, 1987).

Both models include a middle transitionary stage. The second, or encounter stage in the organizational model encompasses the newcomer's entry into the new organization. The interview is past and the actual job begins, but the individual has not yet become a full participating member of the new environment. Van Gennep's second stage is the 
transition stage, which occurs between the old and new situation. The individual has separated from his or her primary groups, and is beginning to experience the new environment. However, the new norms and rules are not yet embraced.

The third stage of the models is an inclusionary process. The organizational model labels it the Metamorphosis stage, in which the newcomer participates and identifies with the new organization. The educational model labels this stage the Incorporation/Integration stage, in which the individual integrates into membership of the new community.

In summary, the interplay between varying levels of institutional and organizational commitment is complex. Understanding the similarities and differences of both models may lead to a more complete understanding of student withdrawal and student persistence.

\section{HYPOTHESES}

Students who have entered their selected institution of higher learning progress through a process of integration. However, the patterns of integration within this process may take place over time, and progress through several stages. Consequently, I propose the following hypotheses: 
H1: The higher the level of expressed commitment the more likely it is that the student will express the intention to remain.

H2: Within terms one, two, and three, the higher the level of expressed commitment the more likely it is that the student will express the intention to remain.

students'personal goal commitments are reciprocally connected to their commitments to their college. students' intentions to remain at their institution may be similar to reasons employees intend to remain with their organization. Therefore, I also propose the following as a research question:

RQ1: Can the organizational assimilation model contribute to understanding the pattern of new student commitment through the encounter stage of integration into an educational institution? 
CHAPTER III

METHODS

The purpose of this study was to determine if the organizational assimilation model can contribute to understanding the pattern of new student commitment through the encounter stage. In particular, the early encounter stage is examined to determine if the organizational model has heuristic value in studying the integration process of students enrolled in an institution of higher education.

\section{SUBJECTS}

The subjects are college students enrolled and attending courses at Portland state University (PSU) during the spring Term of 1992. The total population during spring Term of 1992 was 12,669 , according to the Institutional Research and Planning office of PSU.

\section{SAMPLE}

A sample of convenience composed of both random and nonrandom participants was drawn from students enrolled in classes within eleven departments." Another portion of the Persuasion, Iinguistics/Teaching English as a Second 
sample was randomly selected from students found outside of the classrooms on the PSU campus. The criteria for final sample selection was students enrolled full-time in the first, second, and third terms.

Six-hundred surveys were distributed. Three-hundredfifty-five surveys were completed and returned and of those, data were compiled from 130 surveys. One-hundred-thirty surveys fulfilled the criteria of full-time students who were enrolled in the first, second, and third terms.

of the 130 remaining surveys, 24 students were enrolled in their first term, 25 students in their second term, and 81 students in their third term. Of the 24 students in the first term, there were: 10 males and 13 females, 18 single and 5 married; and 11 White, 3 Black, and 5 Asian. of the 25 students enrolled in their second term, there were: 8 males and 18 females; 16 single, 7 married, and 1 divorced; and 21 White, 1 Black, 1 Hispanic, and 2 Asian. of the 81 students enrolled in their third term, there were: 31 males and 51 females; 64 single, 11 married, and 3 divorced; and 63 White, 4 Black, 4 Native American, and 9 Asian.

The approximate duration of the encounter stage can be approximately one year in length (Feldman, 1981). Each term consists of approximately ten weeks each. Three terms are equal to approximately one year in length. Therefore, this

Language, Physics, Psychology, Engineering statistics, Business statistics, Introduction to speech, Accounting, and Health and Fitness. 
researcher selected students enrolled up through three terms.

The early encounter stage is a crucial period of adjustment and development of commiting attitudes and behaviors covering the newcomer's first day up to approximately one year (Berlew \& Hall, 1966; Crampton, Mowday, Porter, \& Smith, 1978; Hall, 1976; and Wanous, 1980). This period can be filled with high stress and conflicts which may make the assimilation process more difficult.

The turnover rate is generally higher during the early stages of employment (Mowday et al, 1982). Similarly, in educational studies of student departure, student withdrawal is generally experienced in the early stages of the college experience. However, these studies do not explicitly state an exact time, but represent approximately one year. Educational studies involved two-year and four-year colleges, private and public universities, and colleges with small and large enrollments. These studies contained a wide range of variables which were applied in a variety of settings (See Cabrera et al, 1992; Pascarella et al, 1981). Therefore, the exact time of student withdrawal was not specifically pinpointed, but occurs during or just after the Freshman year (Tinto, 1975). 
INSTRUMENT

The survey consisted of a) demographic data, b) scales, and c) open-ended questions. The questionnaire addressed student commitment to PSU, level of student satisfaction, percentage of certainty that the student intended to return to PSU and receive a degree, reasons for returning or not returning to $\mathrm{PSU}$, and who most influenced the student and why. The questionnaire consisted of two subscales on commitment and satisfaction. It also consisted of questions designed by this researcher.

\section{Commitment}

Commitment was measured using questions developed by Porter and Smith in 1970. They attempted to incorporate the three aspects of attitudinal commitment within 15 items. Attitudinal commitment is characterized by: 1) a solid confidence and acceptance of organizational values and goals; 2) an eagerness to work for the good of the organization; and 3) a motivation to remain a member of that organization. However, this researcher altered the organizational wording to accomodate the questionnaire being used in an educational institutional setting. These adaptations are discussed more in-depth in the ANALYSIS section.

The original study of employee-organization linkage began approximately thirty years ago, funded by a military 
grant awarded to Lyman Porter and Robert Dubin. A longitudinal study was conducted surveying 2,563 employees holding various types of jobs in nine private and public organizations. Analyses used in this study were: 1) standard deviations and means; (2) internal consistency reliability; (3) test-retest reliability; (4) convergent validity; and (5) discriminant validity. Also, OCQ raw scores from Porter and Dubin's original study were compared to $O C Q$ raw scores for males and females, based on results of studies which were conducted up until 1979 (Mowday, steers, \& Porter, 1979).

Mowday, Porter, and Steer's (1982) study samples of employees holding jobs in private and public organizations contained an acceptable distribution of responses, ranging from 4.0 to 6.1 across the nine organizations participating in the study. Internal consistency reliability tests of coefficient alpha, item analysis, and factor analysis were calculated. The 15 items had a coefficient alpha which ranged from .82 to .93 , with a median of .90 . Commonly used as acceptable standards are .90 or .95 (Babbie, 1992). Results of the item analyses showed that each item had a positive correlation with the total score, ranging from . 36 to .72 and a median correlation of .64. A value of .64 falls within the acceptable range of 'considerable' correlation (Babbie, 1992). Results of the factor analyses concluded the items measured the single common construct of 
commitment. The test-retest reliability results compared favorably to other attitude measures such as job satisfaction. The reported test-retest reliabilities ranged from .45 to .75. Values of $.70, .80$, or more indicate a high correlation (Babbie, 1992). Difficulty arose in solidly establishing convergent validity for a measure of organizational commitment, but results suggest a moderate convergent, discriminant, and predictive validity, especially when compared against other similar attitude measures.

\section{Satisfaction}

Satisfaction was measured using a seven-point language intensity scale developed by Mortensen, Arnston, and Lustig (1977) (see Appendix C). This Likert-type scale was reported to have internal consistency. The coefficient measured .89. This value falls within the expected optimum level of consistency of .80 and above among the test items (Babbie, 1992).

The Pearson test-retest results showed the reliability coefficient to be .908 . In measuring the five major components, all five accounted for approximately half of the tests' variance; an acceptable value (Babbie, 1992). This researcher also conducted a test for reliability by executing the SPSSX RELIABILITY procedure. The reliability coefficient was .902 . 
I also conducted a pilot study. I decided to develop a few questions of my own upon the suggestion of faculty members from the Communication Department. I also studied a survey of new Freshmen conducted during the Fall of 1991 by a faculty member and administrator of Portland state University. After discussing that survey with the author I added a few questions which would cover some issues not covered by the 1991 survey.

The length of the survey is seven pages. Students completed the survey in approximately thirty minutes for those who chose to remain in the classroom after class. The completion time is unknown for those who completed the survey outside of class and returned the survey during the next class meeting time. Surveys were collected in person or from a drop site within two weeks of distribution.

\section{ANALYSIS}

For this thesis, I did not include an analysis of every question asked in the seven page survey questionnaire. I decided to analyze other questions for a future study. The sections I analyzed only pertained to issues of commitment and correlating concepts pertaining to commitment, such as satisfaction and intentions to return to complete the degree. I analyzed the 15 commitment questions (Section IIQ\#1-Q\#15), two satisfaction questions (Section I-Q\#15 and Q\#17), one question of intention to return (Section I-Q\#19) 
and one question of intention to remain (Section II-Q\#27). I also analyzed the content of one open-ended question (Section I-Q\#20), which is an answer to Q\#19. Table I lists the 15 commitment questions.

\section{TABLE I}

OCQ COMMITMENT QUESTIONS

I. I am willing to put in extra effort to help PSU be
successful. no no no yes ye YES YES!

2. I tell my friends this is a great university to attend.

3. I feel very loyal to PSU.

4. My values are similar to PSU's values.

5. I am proud to tell others that I am part of PSU.

6. I could just as well be educated in a different college or university.

7. PSU inspires my very best performance.

8. It would be easy for me to leave PSU.

9. I am glad I chose PSU over all others.

10. There's little to be gained by staying with PSU.

11. I find it easy to agree with PSU's stated policies (e.g. Student Handbook/Bulletin).

12. I really care about the fate of PSU.

13. This is the best of all possible colleges/universities I could have attended.

14. Deciding to enroll at PSU was a mistake.

15. Attending PSU is satisfying. 
Table II includes the questions that measured students' perceived satisfaction levels of their very first encounter with PSU and their present experience at PSU.

\section{TABLE II}

\section{SECTION II SATISFACTION QUESTIONS}

13. MY very first encounter with PSU was:

Very unsatisfactory

$1 \quad 2$

4

Very satisfactory

$5 \quad 6 \quad 7$

17. MY present experience at PSU is:

Very unsatisfactory

$12 \quad 3$

4

Very satisfactory

$5 \quad 6 \quad 7$

Table III includes questions that asked students' intentions to return or not to return to PSU and a follow-up open-ended question about their reasons for returning or not returning.

TABLE III

SECTION I

INTENTIONS TO RETURN OR NOT TO RETURN AND

REASONS FOR PLANNING TO RETURN OR NOT TO RETURN

19. Do you intend to return to PSU to take additional classes?

Yes

No

20. Please explain your reasons for either planning to return or planning not to return: (open ended question) 
Table IV contains the question that asked the students' intentions to remain and receive their degree from PSU.

\section{TABLE IV}

SECTION II PERCENTAGE OF INTENTION TO REMAIN

27. What is the chance that you will remain with PSU until you receive your degree? Write in a number between $0 \%$ and $100 \%$ to indicate the chance you will remain here. 8

\section{Adaptations}

This thesis survey uses an adapted version of the Mowday, Porter, and Steers (1982) instrument, the Organizational Commitment Questionnaire (OCQ). The OCQ consists of fifteen commitment questions (see Appendix B).

The adaptations consist of changing workplace vocabulary, such as employee, organization, job, work, job performance, to fit academic institution vocabulary, such as student, institution, university, PSU, and performance.

other adaptations were made, based on instrument testing in a pilot study of five undergraduate and five graduate students. These students provided verbal and written feedback when they completed the questionnaire. Two general suggestions were incorporated into the final adapted version of the questionnaire: (1) Include more questions regarding diversity issues, and (2) ask a question about how students survive while in college, such as academically, 
emotionally, or monetarily. Table $\mathrm{V}$ indicates additions to the questionnaire which reflect issues of diversity. The diversity questions address ethnic intercultural issues.

\title{
TABLE V \\ SECTION II DIVERSITY QUESTIONS
}

16. I feel that I socially belong at PSU.

17. I feel that I have adequate opportunity at PSU to hear speakers to whom I can relate.

18. I feel that I am treated fairly in my classes at PSU.

19. I feel my PSU instructors/professors are sensitive to me.

20. I feel that the curriculum at PSU adequately reflects cultural diversity.

21. I feel that the PSU faculty treats minority students fairly.

25. I have had the opportunity to interact with people from diverse cultures.

26. Interaction with people from diverse cultures is important to me.

28. What does it take to do well as a PSU student?

Table VI includes the open-ended question that was added so as to incorporate the student survival issue.

\author{
TABLE VI
}

SECTION II STUDENT SURVIVAL QUESTION

28. What does it take to do well as a PSU student? 
All statistical analyses were conducted using SPSSx and PCSTAR computer software. The statistical analyses used were: a) Pearson Correlations and b) a Reliability test. Correlations were calculated on non-categorical scale items, continuous, and dichotomous variables. A positive correlation occurs when one value of a variable increases and the value of the other variable increases as well (Frey, Botan, Friedman, \& Kreps, 1991). I devoted particular attention to medium to highly correlated areas with a correlation coefficient $r$ value between .40 and .90 , and a probability of less than .05 on the pearson table. I correlated levels of satisfaction of the students' first encounter to their present experience. I ran frequencies on how many said they planned to return or not return. I correlated the answers to $Q \# 1-Q \# 15$. I ran a frequency test on the percentage of certainty students believed they would remain at $\mathrm{PSU}$ to receive their degree.

\section{CONTENT ANALYSIS}

A thematic analysis was conducted on one open-ended question which was:

\#20. Please explain your reasons for either planning to return or planning not to return:

The researcher contends answers to this question may directly relate to student's reasons for intentions to 
remain or withdraw. Individual's intentions are components in both the organizational model and the institutional model.

Analysis Method

Content analysis, according to Frey et al (1991), "is a powerful method for analyzing texts that is useful to theorists, researchers, practioners, and consumers alike ( $p$. 215)." More specifically, thematic units were selected to analyze topics contained within the open-ended answer. Categories were created from thematic topics, such as personal commitment, proximity, financial, major or program considerations, and teaching considerations. Each student might respond with several reasons for returning or not returning. If a student mentioned answers that fell into more than one of the preceeding five categories, each specific reason was calculated once per student.

Content analysis was selected as a method of studying the data because it augmented the structured questions with unstructured information from the respondents. The intent of the researcher is to discover underlying motivations, beliefs, and attitudes which may enhance the answers to the 15 structured questions, which were to measure student commitment levels within the encounter stage.

However, Iimitation may arise in using thematic content analysis in that the respondents may not provide complete, accurate information, due to time constraints or difficulty 
in accurate recall. In my study, there were more unanswered questions toward the end of the survey than there were in the first pages of the questionnaire.

\section{Commitment scale Limitations}

A potential difficulty that may arise with the use of this entire survey is that the respondents may easily falsify their answers if they are so inclined. The intent of some of the items is not disguised, therefore the respondents' answers could be falsely manipulated. The respondents' answers may also reflect a fear of the possibility that their answers may be used against them. This caveat, however, is more relevant when studying employee-employer linkage. If employees believe their answers representing commitment to their organization might be interpreted as disloyalty, they may answer more positively because they fear not being promoted or being fired.

When the OCQ is used to study the commitment levels of college students, the opposite effect might be possible. Students may answer with excessively negative responses so as to vent their dissatisfaction about more issues than those mentioned in the survey, since they have no fear of reprisal. Employees may fear reprisal such as losing their job, or being passed over for a promotion, if their confidentiality is not honored and their commitment answers are read by their supervisors. 
The primary difficulty that arises when evaluating the efficacy and limitations of the OCQ is the vast range of types of organizational commitments that have been researched. This limitation is discussed in chapter Two, under the commitment secondary subheading, which is located under the primary subdivision, ORGANIZATIONAL ASSIMILATION THEORY BACKGROUND.

\section{PROCEDURES}

\section{Distribution}

I obtained permission to distribute the survey at Portland State University from instructors and heads of three departments at PSU. I also obtained approval from the Portland State Human Subjects Committee.

I came to the designated classes on the approved day. The professors briefly introduced me as a graduate student from the Department of Speech Communication working on her thesis.

After the introduction I stated my name and asked for the students' help in compiling data to complete my study on student commitment to PSU. If they decided to participate in the survey, I asked them to first read and sign the Consent Form (see Appendix A). I also informed them that they were free to withdraw from the research project at any time; participation was voluntary. The participants were assured confidentiality. I told them their consent Form was 
a separate paper and not attached to the questionnaire in any way, so as not to connect a student's name with their questionnaire responses. If the student-respondents signed the consent Form, they were then asked to fill out the demographic sheet (see section I - Appendix B) and the questionnaire (see section II - Appendix C). The completed surveys were gathered and placed in sealed envelopes.

I also approached students on the campus in the Park street area and asked them if they would participate in my study. I stated my name and told the student I was a graduate student from the Department of Speech Communication, working on my thesis. If they agreed to participate, I gave them the consent Form to read and sign, then gave them the questionnaire. I waited until they completed the questionnaire and then placed the consent Form in one manilla envelope and the completed survey in another. 


\section{CHAPTER IV}

\section{RESULTS}

This chapter discusses the results obtained using SPSSx and PCSTAT computer analysis software. All the tests were calculated in an attempt to answer the research question of this study: Can the organizational assimilation model contribute to understanding the pattern of new student commitment through the encounter stage of integration into an educational instutition?

A breakdown of the demographics of students enrolled full-time enrolled during their first, second, and third terms returned surveys will be presented first. Included in the table is the total number of PSU students within a particular category enrolled during the Spring Term of 1992. The reliability test and correlation results will be reported.

\section{DEMOGRAPHICS}

Student's ages ranged from 18-38 years of age enrolled in the first term, 19-39 years of age enrolled in the second term, and 18-47 years of age enrolled in the third term. Table VII includes demographical information from my survey and the PSU 1992 Fall Fact Book. 
TABLE VII

SURVEY DEMOGRAPHICS AND

DEMOGRAPHICS FROM FALL FACT BOOK, 1992

\begin{tabular}{|c|c|c|c|c|}
\hline Variable & Term 1 * & Term $2 *$ & Term $3 *$ & $\begin{array}{c}\text { PSU } \\
\text { Total ** }\end{array}$ \\
\hline Men & 9 & 8 & 31 & 6,769 \\
\hline Women & 15 & 17 & 50 & 7,516 \\
\hline $\begin{array}{l}\text { Marital } \\
\text { Status } \\
\text { Single } \\
\text { Married } \\
\text { Divorced } \\
\text { Other }\end{array}$ & $\begin{array}{r}17 \\
6 \\
0 \\
0 \\
\end{array}$ & $\begin{array}{r}15 \\
7 \\
1 \\
2 \\
\end{array}$ & $\begin{array}{r}63 \\
11 \\
3 \\
4 \\
\end{array}$ & $\begin{array}{l}\text { Missing } \\
\text { Missing } \\
\text { Missing } \\
\text { Missing }\end{array}$ \\
\hline $\begin{array}{l}\text { Average } \\
\text { Age } \\
\text { Men } \\
\text { Women }\end{array}$ & $\begin{array}{l}22.2 \\
23.4\end{array}$ & $\begin{array}{l}23.7 \\
23.1\end{array}$ & $\begin{array}{l}22.5 \\
23.8\end{array}$ & $\begin{array}{l}28.1 \\
29.4\end{array}$ \\
\hline $\begin{array}{l}\text { Age } \\
\text { Distrib. } \\
16-20 \\
\text { Male } \\
\text { Female } \\
21-25 \\
\text { Male } \\
\text { Female } \\
26-30 \\
\text { Male } \\
\text { Female } \\
31-35 \\
\text { Male } \\
\text { Female } \\
36-40 \\
\text { Male } \\
\text { Female } \\
41-45 \\
\text { Male } \\
\text { Female } \\
46-50 \\
\text { Male } \\
\text { Female } \\
51-55 \\
\text { Male } \\
\text { Female } \\
56+ \\
\end{array}$ & $\begin{array}{l}5 \\
5 \\
1 \\
5 \\
2 \\
1 \\
1 \\
1 \\
0 \\
3 \\
1 \\
0 \\
0 \\
0 \\
0 \\
0\end{array}$ & $\begin{array}{l}3 \\
4 \\
4 \\
9 \\
0 \\
4 \\
0 \\
0 \\
1 \\
0 \\
0 \\
0 \\
0 \\
0 \\
0 \\
0\end{array}$ & $\begin{array}{l}10 \\
21 \\
15 \\
15 \\
1 \\
7 \\
2 \\
7 \\
1 \\
1 \\
0 \\
0 \\
0 \\
1 \\
0 \\
0\end{array}$ & $\begin{array}{r}888 \\
1,040 \\
2,398 \\
2,420 \\
1,382 \\
1,228 \\
858 \\
839 \\
598 \\
817 \\
368 \\
665 \\
181 \\
345 \\
47 \\
104\end{array}$ \\
\hline Undergrad & 19 & 24 & 77 & 10,502 \\
\hline Graduate & 5 & 1 & 4 & 3,783 \\
\hline
\end{tabular}


TABLE VII

SURVEY DEMOGRAPHICS AND

DEMOGRAPHICS FROM FALL FACT BOOK, 1992 (continued)

\begin{tabular}{|l|r|r|r|r||}
\hline Variable & Term 1* & Term 2* & Term 3* & $\begin{array}{r}\text { PSU } \\
\text { Total ** }\end{array}$ \\
\hline Ethnic & & & & \\
Origin & 12 & 20 & 62 & 9,996 \\
White & 3 & 1 & 5 & 320 \\
Black & 0 & 1 & 0 & 295 \\
Hispanic & 7 & 2 & 9 & 1,008 \\
Asian & 2 & 1 & 5 & Missing \\
Other & 14 & 19 & 56 & Missing \\
\hline Transfer & & & & \\
\hline
\end{tabular}

* Data collected during Spring Term, 1991-1992 year

** Data covering Fall Term of 1991-1992 year, 4th week

\section{SCALE RELIABILITY}

The reliability of the fifteen items used to test commitment were computed by SPSSx Reliabilities. This scale is highly reliable (alpha $=.90$ ). The reliability score of the commitment questions of Mowday, et al (1982) was also alpha $=.90$. The reliability score of the satisfaction questions was alpha $=.87$.

\section{HYPOTHESES TESTS}

The two hypotheses related to the overall question of this study were tested using spssx Correlations. The dependent variable (DV) of commitment was compared to intent to remain. 
H1: The higher the level of expressed commitment to Portland State University the more likely it is that the student will express the intention to remain. The correlation between commitment and intent to remain is $r=.02$, with no significance. The null hypothesis cannot be rejected.

H2: Within terms one, two, and three, the higher the level of expressed commitment the more likely it is that the student will express the intention to remain. The correlation between commitment and intent to remain for Term one is $r=.32$, and marginally significant at $p<$ .07 . The correlation between commitment and intent to remain for Term Two is $r=.04$, with no significance. Finally, the correlation between commitment and intent to remain for Term Three is $r=.01$, with no significance. The null hypothesis cannot be rejected.

In view of the overall lack of correlation, it is probable that the relatively low correlation in Term one is a random occurance. After examining the Pearson test, a content analysis was conducted due to a lack of correlation in the quantative analysis. This researcher looked for further evidence of commitment patterns by studying verbatim answers to 220 , the open-ended question. Frequencies were calculated on answers to the open-ended question in relation to their answers to Question \#19: I will return or I will not return: YES or NO (which is the dependent variable which 
represents commitment). Each student could respond with several reasons for returning or not returning. Table VIII lists the categories and examples which illustrate each category, and the total number of responses in each category for the reasons given for "yes" the student intends to return and "no" the student does not intend to return.

\section{TABLE VIII}

CATEGORIES OF OPEN-ENDED QUESTION \# 20 EXPLAIN YOUR REASONS FOR RETURNING OR NOT RETURNING

\begin{tabular}{|c|c|c|c|}
\hline Category Name & $\begin{array}{l}\text { Examples of "Yes" } \\
\text { and "No" Student } \\
\text { Responses }\end{array}$ & \multicolumn{2}{|c|}{$\begin{array}{l}\text { Total Number } \\
\text { of YES \& NO } \\
\text { Responses from } \\
\text { All } 3 \text { Terms } \\
\text { YES NO }\end{array}$} \\
\hline $\begin{array}{l}\text { Personal Commitment } \\
\text { to Receiving the } \\
\text { Degree }\end{array}$ & $\begin{array}{l}\text { 1. To complete my } \\
\text { degree } \\
2 \text {. I've gotta } \\
\text { graduate and get my } \\
\text { accounting degree } \\
\text { from PSU. } \\
3 . \quad \text { I'm graduating. }\end{array}$ & 58 & 0 \\
\hline Proximity & $\begin{array}{l}\text { 1. The area is } \\
\text { good for job } \\
\text { opportunities. } \\
2 \text {. I'm close to my } \\
\text { family. } \\
3 \text {. I'm leaving } \\
\text { here to transfer to } \\
\text { osu. }\end{array}$ & 25 & 5 \\
\hline
\end{tabular}


TABLE VIII

CATEGORIES OF OPEN-ENDED QUESTION \# 20

EXPLAIN YOUR REASONS FOR RETURNING OR NOT RETURNING (continued)

\begin{tabular}{|c|c|c|c|}
\hline Category Name & $\begin{array}{l}\text { Examples of "Yes" } \\
\text { and "No" Student } \\
\text { Responses }\end{array}$ & \multicolumn{2}{|c|}{$\begin{array}{l}\text { Total Number } \\
\text { of YES \& No } \\
\text { Responses from } \\
\text { AlI } 3 \text { Terms } \\
\text { YES }\end{array}$} \\
\hline $\begin{array}{l}\text { Major \& Program } \\
\text { considerations }\end{array}$ & $\begin{array}{l}\text { 1. I like the } \\
\text { program I'm in and } \\
\text { I would lose too } \\
\text { many credits if I } \\
\text { transferred now. } \\
2 \text {. I worked so } \\
\text { hard to get into } \\
\text { the Business } \\
\text { Program and don't } \\
\text { want to leave now. } \\
3 \text {. I won't be back } \\
\text { because they cut my } \\
\text { program. }\end{array}$ & 29 & 4 \\
\hline $\begin{array}{l}\text { Academic } \\
\text { considerations }\end{array}$ & $\begin{array}{l}\text { 1. The teachers } \\
\text { here seem to } \\
\text { understand me and } \\
\text { try to help me a } \\
\text { lot. They are } \\
\text { sympatehtic and } \\
\text { friendly. } \\
2 \text {. The teachers in } \\
\text { my program are } \\
\text { wonderful. The } \\
\text { rest leave much to } \\
\text { be desired. I'm } \\
\text { sure not satisfied } \\
\text { with the } \\
\text { administrative } \\
\text { aspects at psU. } \\
3 \text { I feel like I'm } \\
\text { just a number, not } \\
\text { a real person. }\end{array}$ & 14 & 4 \\
\hline
\end{tabular}


In view of $\mathrm{H} 1$ and $\mathrm{H} 2$ not being supported, the research question is also not supported. The research question reads:

R1: Can the organizational assimilation model contribute to understanding the pattern of new student commitment through the encounter stage of integration into an educational institution?

Even though both models involved similar processes of assimilating and integrating, individuals' underlying motivations are quite different. Therefore, due to the differences between employee motivation and student motivation, the organizational model had little utility in studying students in an educational environment. 
CHAPTER V

DISCUSSION

The purpose of this chapter is to interpret the results reported for each of the two hypotheses and to discuss the research question. This discussion will examine the hypotheses, and then focus on the overall question of this study: Can the organizational assimilation model contribute to understanding the pattern of new student commitment through the encounter stage of integration into an educational institution?

\section{HYPOTHESES}

Neither hypotheses of this study was supported. A Pearson Correlation test revealed no significant correlation between commitment and intent to remain for either hypothesis (one or two). Possible explanations for the results will be explored in the following discussion.

H1: The higher the level of expressed commitment to Portland State University, the more likely it is that the student will express an intention to remain. The results of Hypothesis 1 , that a high percentage of the 355 subjects who reported that they were 80 to 100 percent certain that they intended to remain and receive their degree yet whose 
commitment levels were low, suggest that personal goal commitment to receiving their degree is stronger than commitment to the institution (see Appendix c).

This result also holds true for Hypothesis 2 . H2: Within Terms one, Two, and Three, the higher the level of expressed commitment, the more likely it is that the student will express an intention to remain. For example, when students (from the larger sample of 355 and the smaller sample from Terms 1,2 , and 3 of 131 students) were asked to rate the satisfaction level with their first encounter at PSU and the current level of satisfaction with their present experience, many students responded with a very low satisfaction rate, 2 or 3 on a scale from 1 (very unsatisfactory) to 7 (very satisfactory), yet stated that they were 80 percent to 100 percent certain that they would return and receive their degree from PSU. Again, this suggests that the students' personal commitment is stronger than their commitment to the institution.

The results of Hypothesis 2 reveal that not only does commitment not increase through the students' third term, the first term commitment was slightly higher than that of term 2 and term 3. Even though the higher first term correlation may have been a result of random occurance, it may suggest that the reactance phenomenon may be a factor. Psychological reactance is based on Brehm's (1966) definition which is "threatening to restrict or actually 
eliminating a person's freedom to act as he or she chooses [which] arouses in that person a motivational drive (Petty \& Cacioppo, 1989, p. 155) . When students perceive their freedom is restricted to enrollment at PSU because of financial or proximity reasons, their behaviors and attitudes may be affected. In turn, as suggested by Petty and Cacioppo (1979) an individual may reevaluate the previous negative feeling of restriction and relable that feeling more positively. Therefore, students may be more likely to voice their opinion they "hate it" at PSU, while concurrently expressing the desire to return and finish their degree because of a lack of perceived choice. The high degree of certainty of students' decision to return may be based on their perceived feeling of a reduced freedom of choice. students may feel dissatisfied with their experiences at the university but feel they must stay due to several types of constrictions. For example, a student commented "I will lose too many credits if I transer to another university, so I can't leave now." Another student said, "I can't transfer out-of-state to another college because my husband has an excellent paying job here, so I'll be back next term." Another student responded "This school is the cheapest in the area. I'd like to have enrolled in a private college, but I couldn't afford it." Tinto (1987) suggested that more qualitative studies are needed so as to more fully understand how the 
integration and withdrawal processes functions. Qualitative responses may offer alternative explanations and interpretations to augment quantitative analyses. To this end, I asked six open-ended questions in my survey questionnaire, but I did not fully analyze these questions for this study. However, I have compiled five broad categories which emerged from the students' answers (see Table VIII).

Specific examples of students' responses which were found in answers to the open-ended question were "Even though I hate it here, I have to stay because I need the skills and degree to get a job that pays a living wage." Another was "The financial aid office lost my paperwork, but I've got so much time and effort into this degree already, I can't quit now. I've got to get my diploma." According to Tinto (1987), the student's integration process includes students' personal goal commitments as well as commitment to the institution in which they are enrolled. He contended that if the student's experiences are perceived as negative, the likelihood that the students will decide to leave thereby increases. In my study, the students responded with answers indicating low satisfaction with their first encounter and low satisfaction with their present experiences. However, they responded with a high degree of certainty they would not leave, but return and continue to work toward their degree in spite of their low satisfaction 
level. Low satisfaction indicates a negative experience, which Tinto contends leads to students decisions to leave (see above quotations of student responses).

Frequencies were calculated for answers to the openended question $(Q \# 20)$. Students indicated their primary reason or motivation for returning to PSU was their intention to receive their degree (58). Student's secondary reason was to return to PSU due to their program and major considerations (29). These results suggest students are motivated not only to getting a college degree but also are concerned with the quality of their education within their designated major or program in which they are enrolled.

My conceptualization of motivation herein may be incorrect, however, in that this study assumes that employee motivation and student motivation are similar. Motivational factors which lead to employee job satisfaction include an outgrowth of achievement, verbal recognition, challenging work, job responsibility, and promotional advancement. When these are present in a job, the employee's basic needs may be satisfied, and positive feelings, as well as improved performance, are likely to result. The basic needs specified are those related to personal growth and selfactualization, and are said to be satisfied by the intrinsic aspects of the work itself (Herzberg, Mausner, \& snyderman, 1959). 
It is also probable that production is simply a very poor - and very misleading metaphor for learning. students are neither clients nor employees. Partners (junior partners) come much closer.

on the other hand, student motivational factors which could lead to student satisfaction are an outgrowth of intrinsic rewards, such positive perceptions of successful interaction with professors and peers during situations involving intellectual and social participation in college life. For example, a student commented, "I love my philosophical discussions with my professor in her office after class. She always gives me lots to think about." However, other students may be motivated by extrinsic factors, such as the perception that they can become gainfully employed in a well-paid position after acquiring a college degree (Tinto, 1987). For example, a student said, "I'm taking my last few classes so I can finally get my diploma. I have a few great job prospects lined up that require a degree."

organizations and institutions both provide climates which either promote healthy interpersonal interaction or barriers which hinder member participation. The students' participation in the formal social system, which includes interaction with their peer-group may effect students' social integration into their institution (Tinto, 1987). 
Portland state is generally categorized as an urban university. This element alone may be a mitigating factor in students' institutional commitment and student participation in activities with their peers. For example, some students commented, "I have trouble getting together with my group to complete a class project because everyone disappears after class. So many said they had to go to work." "I have tried to see my professor after class to talk over a complex assignment, but he's never there." Portland state University is in close proximity to jobs and family. Students work several hours, attend a few classes, than return to their work or home. Because of PSU's downtown location, walking from school to a job site is often possible. Commuting is facilitated by using the city's mass transit system or by using a personal vehicle. Only a few students live on-campus in residence halls at PSU, with a large number of students living in nearby residential areas. "Commuter institutions as a group may differ substantially from residential institutions in the educational, cultural and social experiences they provide students (Pascarella, Duby, \& Iverson, 1983, p. 99)." students have diverse support systems on which to rely, such as nuclear and extended families who live nearby, instead of relying on only dormitory or campus apartment friends.

The following comments illustrate socialization among students, their faculty, and peers. "I've become so much 
closer to my classmates because they're the ones who really helped me with my scheduling problems and tough assignments." Another student commented, "My psychology prof is so wonderful. She's taken a special interest in me, which makes me feel like a real person, not just a number." Another student said, "If it weren't for my friends here at PSU, I would have left long ago." Tinto (1987) indicated that there is an important interplay between the social and academic elements of student life.

\section{RESEARCH QUESTION}

The research question is: Can the organizational assimilation model contribute to understanding the pattern of new student commitment through the encounter stage of integration into an education institution.

In the organizational model, commitment is conceptualized as playing an important role in the assimilation process. Specifically, there exists a linkage between employees and their organization (Mowday et al, 1982). However, linkages between employees and their organization can be different from those between students and their institutions. Organizations provide opportunities for promotional advancement for their employees, while institutions are not involved in this type of opportunity for students. 
Another component of commitment in the organizational model is the congruence between an individual's values and the values of the organization. Organizations have policies which may or may not match the values of the employees. Institutions have rules and regulations which may or may not match the values of their students. Thus, employees may perceive organizational fit and students may perceive institutional fit in the same manner. In reference to the educational model, regarding the issue of a perceived match of student values to college policies, several students wrote comments in the margins next to Question 11: "I find it easy to agree with PSU's stated policies (e.g. student Handbook or Bulletin)." The students appeared unaware of their university's rules and regulations. These comments included "What are they anyway, I don't have the foggiest notion"; "How should I know, I don't care about the policy section of the Handbook."; and "I just read about the course descriptions, not the campus policies." Apparently, for these students, institutional fit may not be an important issue or even relevant.

Perhaps students refuse to read the policies in the Student Handbook. Students may make a conscious decision not to read the policies, making a declaration of selfidentity. The students may also not be motivated to fit themselves to the institution, but that does not mean there is not an institutional fit. 
Interpersonal interaction is an element in the educational model. The question is, what point in time do interpersonal interactions take place that will produce the most positive effects? If new students entering college for the first time do not know anyone on campus from a previous interaction, it is likely it will take time throughout the term to establish and develop interpersonal relationships. Therefore, students may perceive their experiences to be more positive beyond the early encounter stage, after their third term.

Some methodology difficulties may have been present. The time of year during which I collected my data (spring quarter) may have been inappropriate. The students were surveyed, in some cases, nine months after their first encounter. Memory decay may have affected their responses (Bernard, 1984). Spring term may be a time when students are tired after a year of intense coursework. Therefore, students may not have taken their time with each question, but merely answered quickly without much thought or without carefully reading each question.

\section{SUMMARY}

Overall, there are many questions that remain unanswered about the assimilation/integration process. Within the organization, greater employee turnover increases the costs of replacing and retraining those employees. The 
employee group cohesion is also interrupted. Cohesion is "group loyalty as well as the group's ability to stick together (Bormann \& Bormann, 1988, p. 55)." Due to turnover, the interruption also results in a likelihood the productivity and morale will decrease (Bormann \& Bormann, 1988). The organization also suffers when people who hold key positions leave. In turn, performance may suffer (Mowday et al, 1982). There are, however, advantages in employee turnover. New employees may breathe new life into the organization by bringing with them innovative ideas, eagerness, and high energy. The remaining employees may receive opportunities for the development of new skills when filling in for former employees. However, organizations continue to search for more ways to cut costs and create climates that are harmoneous and productive.

The issue of student turnover, or dropout, is a different issue. Portland State University is an urban, centrally located, commuter college. Many stressors face the students who have a tendency to attend this type of institution, such as the struggle to maintain employment, provide for their families, and continue with their education all at the same time. Reasons for dropout in this kind of institution are many and varied and thus, understanding the reasons for student dropout at PSU is a complex undertaking well beyond the scope of this study. 
Using an organizational model to understand behaviors and attitudes in an academic setting may have little heuristic value. Some of the same underlying theories of human behavior, whether individuals are exhibiting integrating or assimilating behaviors or making decisions to remain or leave an organization or institution, does not reduce the fact that these two models cannot be used interchangeably within the two domains. Therefore, the heuristic value of applying an organizational model to the study of individuals interacting within the educational setting may be of little consequence.

In conclusion, there are two important results that can be drawn from this study. First, with respect to the urban, commuter college student, there is no way empirically to discriminate between commitment to their institution and intention to remain and receive their degree. Second, the organizational model of assimilation is not the most effective model to use in the study of student integration. Crossing domains in this direction appears to have little utility.

SUGGESTIONS FOR FURTHER RESEARCH

Because interpersonal interaction is an important component in student integration (Tinto, 1987), perhaps a questionnaire dealing more with the students' interpersonal interactions might lead to a clearer understanding of the 
students' commitment and integration process. Conducting a turning point analysis might pinpoint a strategic event or encounter that strengthens commitment to persist and receive a degree, in spite of reported dissatisfaction among students. A turning point analysis might also pinpoint an event or encounter which may lead individuals to change from outsiders to in-group members (Bullis \& Bach, 1989). Bullis and Bach (1989) define a turning point "as any event or occurrence that is associated with change in a relationship" (p. 276).

The study of commitment levels of students enrolled longer than the third term might also be more appropriate and produce more reliable data. Conceptually the metamorphosis stage, which can occur after one year, is considered to be the time when individuals are likely to change from an out-group member into an in-group member (Jablin et al, 1987). Therefore, data collected after the third term may provide more significant information about which kind of commitment is involved in the integration process.

Further research needs to be conducted on intercultural issues and where these issues fit into the integration process. Tinto (1982) suggested there is a call for more qualitative research. Therefore, an ethnographic study could be conducted of interviews of individuals from different cultures. Intercultural issues are particularly 
important because PSU is a university with large student numbers that are culturally and ethnicly diverse. I asked eight questions on diversity. A further analysis could be conducted on students' perceptions of diversity and where this component might impact the student integration process.

\section{FUTURE IMPLICATIONS}

During the time in which Jablin et al (1987) and Mowday et al (1982) studied assimilation and commitment, the attributes of employee loyalty and devotion were associated with employees' commitment to their organization. These attributes may no longer be perceived to be as important as they formerly were.

Currently, companies are often bought out by larger companies. Employees are terminated when new administrations come into power after corporate takeovers. Therefore, employees may no longer perceive that their organization is loyal to them. Reciprocally, employees in turn may feel less loyal to their organization, increasing possible intentions to leave. Employment with one company during an employee's entire career seems to have become a relic of the past. Moreover, employees in the 1990s voluntarily change careers more often than they did in the past four decades, when many of the organizational commitment studies began. This may be an indicator of lessening devotion and loyalty to the organization. 
Another contemporary change is the new phenomenon of employees working out of their homes. The organization provides the employee with a computer and modem. Work is completed at a home site and sent by telecommunication networks to the work location, without the employee physically being on site at the organization's location. Interpersonal interaction with peers and supervisors is minimal. This factor decreases employees' chances for organizational participation. The employee is physically not absorbed into the culture of an organization, which Jablin (1982) contended is an integral part of the assimilation process. "The information society will bring forth new structures. And the companies re-inventing themselves are already evolving toward that new reality (Naisbitt \& Aburdene, 1985, p. 295)." This suggests we are on the brink of reconceptualizing the organizational model. The educational model may also be on the brink of reconceptualization. Portland state is part of a program called Distance Learning or Distance Education. Students working on a Masters of Business Administration (MBA) pay a fee and participate through cable television. students watch lectures through their own television, or purchase required video cassette tapes. Once a month they mail in written materials for instructors to grade. Also once a month, they go to a predesignated location on the PSU campus for personal instruction. 
This instructional method reduces students' interpersonal interaction with peers and faculty, which may alter students' motivation to fit in, thus reducing their desire to participate in their new environment. This, in turn, decreases the likelihood of integrating into the campus environment (Tinto, 1987). The integration process must contain some form of inclusionary practice involving interaction with other individuals. Since peer support plays an important role in encouraging students to persist in college, the reduction of opportunities for students' physical presence on campus may reduce the opportunities for students to become integrated members of their institution (Tinto, 1987). "The curious transformation of corporations into universities [training programs] and universities into businesses is an analogue for what is going on throughout this society. We used to be able to divide our institutions into neat little boxes and say this is a school, this is a business. But now we are erasing the lines that draw the boxes" (Naisbitt \& Aburdene, 1985, p. 298)." 


\section{REFERENCES}

Angle, H. L. \& Perry, J.L. (1981). An empirical assessment of organizational commitment and organizational

effectiveness. Administrative science Quarterly, 26, 112 .

Babbie, E. (1992). (6th ed.). The practice of social research. Belmont, CA: Wadsworth Pub.

Bean, J. P. (1980). Dropouts and turnover: The synthesis and test of a causal model of student attrition. Research in Higher Education, 12, 155-187.

Bean, J. P. (1983). The application of a model of turnover in work organizations to the student attrition process. the Review of Higher Education, $\underline{6}, 129-148$.

Bean, J. P. (1985). Interaction effects based on class level in an explanatory model of college student dropout syndrome. American Educational Research Journal, 22, $35-64$.

Bean, J. P. \& Metzner, B. S. (1985). A conceptual model of nontraditional undergraduate student attrition. Review of Educational Research, 55, 485-540.

Becker, H.S. (1960) . Notes on the concept of commitment. American Journal of Sociology, $66,32-42$.

Berger, C. R., \& Calabrese, R. J. (1975). Some explorations in initial interaction and beyond: Toward a developmental theory of interpersonal communication. Human Communication Research, 2, 99-112.

Berlew, D. \& Hall, D. (1966). The socialization of managers: Effects of expectations on performance. Administrative science Quarterly, 2, 207-223.

Bernard, H., Killworth, P., Kronefeld, D., \& Sailor, L. (1984). The problem of informant accuracy: The validity of retrospective data. Annual Review of Anthropology, $13,495-517$.

Bormann, E. G., \& Bormann, N. C. (1988). Effective small group communication (4th ed.). Burgess Publishing. 
Brehm, J. W. (1966) - A theory of psychological reactance. New York: Academic Press.

Brown, M. H. (1985). That reminds me of a story: speech action in organizational socialization. Western Journal of Speech Communication, 49, 27-42.

Buchanan, B., II. (1974). Building organizational commitment: The socialization of managers in work organizations. Administrative Science Quarterly, 19, 533-546.

Bullis, C. \& Bach, B. (1989). Socialization turning points: An examination of change in organizational identification. Western Journal of Speech Communication, 53, 273-293.

Cabrera, A. F., Castaneda, M. B., Nora, A., \& Hengstler, D. (1992). The convergence between two theories of college persistence. Journal of Higher Education, 63, 143-164.

Cheney, G. (1983). The rhetoric of identification and the study of organizational communication. Quarterly Journal of Speech, 69, 143-158.

Cheney, G. \& Tompkins, P. K. (1987). Coming to terms with organizational identification and commitment. Central States Speech Journal, 38, 1-15.

Christie, N. G. \& Dinham, S. M. (1991). Institutional and external influences on social integration in the freshman year. Journal of Higher Education, 62, 412436 .

Covner, B. J. (1950). Management factors affecting absenteeism. Harvard Business Review, 28, 42-48.

Crampon, W., Mowday, R., Smith, F., \& Porter, L. W. (1978). Early attitudes predicting future behavior. Paper presented at the 38 th annual meeting of the Academy of Management, San Francisco, August.

Crites, J. O. (1969) - Vocational psychology. New York: McGraw-Hill. 
Cutrona, C. E. (1982). Transition to college: Loneliness and the process of social adjustment. In Loneliness: A sourcebook of current research, theory and therapy. Edited by L. Peplau and D. Perlman. New York: John wiley and Sons.

Dunnette, M. D., Avery, R., \& Banas, P. (1973). Why do they leave? Personnel, 50, 23-39.

Durkheim, E. (1951) . Suicide. Translated by J. A. Spaulding and G. Simpson. Glencoe: The Free Press. Originally published as Le suicide: Etude de sociologie. Paris: Felix Alcan, 1897 .

Eisenberg, E. M., Monge, P. R., \& Miller, K. I. (1983). Involvement in communication networks as a predictor of organizational commitment. Human Communication Research, 10, 179-201.

Feldman, D. C. (1976). A contingency theory of socialization. Administrative Science Quarterly, 21, 433-452.

Feldman, D. C. (1977). The role of initiation activities in socialization. Human Relations, 30, 977-990).

Frey, L. R., Botan, C. H., Friedman, P. G. \& Kreps, G. L. (1991). Investigating communication: An introduction to research methods. Englewood Cliffs, NJ: Prentice Hall.

Gommersall, E. R., \& Myers, M. S. (1966). Breakthrough in on-the-job training. Harvard Business Review, 44, 6272 .

Gouldner, A. W. (1957). Cosmopolitans and locals: Toward an analysis of latent social roles. Administrative Science Quarterly, 2., 281-306.

Graen, G. B., Orris, J. B., \& Johnson, T. W. (1973) . Role assimilation processes in a complex organization. Journal of Vocational Behavior, 3 , 395-420.

Hall, D. (1976). Careers in organization. Santa Monica: Goodyear.

Herzberg, F., Mausner, B., Peterson, R. O., \& Capwell, R. (1957) - Job attitudes: Review of research and opinions. Pittsburgh: Pittsburgh Psychological Services. 
Jablin, F. (1982). Organizational communication: An assimilation approach. In M. E. Roloff \& C. R. Berger (Eds.), Social cognition and communication. (pp.255624). Beverly Hills, CA: Sage.

Jablin, F. M. (1984). Assimilating new members into organizations. In R. Bostrom (Ed.), Communication Yearbook, 8 , 594-626. Newbury Park, CA: Sage.

Jablin, F. M. (1985). An exploratory study of vocational organizational communication socialization. Southern Speech Communication Journal, 50, 262-282.

Jablin, F. (1986). What is organizational assimilation? An overview of communication, socialization, and individualization processes. In L. Putnam (Chair) Communication and organizational socialization. Preconference constructed at the meeting of the International Communication Association, Chicago.

Jablin, F. M. \& Krone, K. J. (1987). Organizational assimilation. In Berger, C. R. \& Chaffe, S. H. (Eds.), Handbook of Communication Science, pp. 711-746. Beverly Hills, CA: Sage.

Jablin, F. M., Putnam, L. L., Roberts, K. H., \& Porter, L. W. (1987). Handbook of organizational communication. Newbury Park: CA: Sage.

Jones, g. R. (1983). Psychological orientation and the process of organizational socialization: An interactionist perspective. Academy of Management Review, $8,464-474$.

Kahn, R. L., Wolf, D. M., Quinn, R. P., Snoek, J. D., \& Rosenthal, R. A. (1964). Organizational stress: Studies in role conflict and ambiguity. New York: Basic Books.

Katz, R. (1980) . Organizational stress and early socialization experiences. In $T$. Beehr \& $R$. Bhagat (Eds.), Human stress and cognition in organization: An integrative perspective (pp. 117-139). New York: John Wiley.

Louis, M. R., Posner, B. Z., \& Powell, G. N. (1983). The availability and helpfulness of socialization practices. Personell Psychology, 36, 857-866.

March, J. G. \& Simon, H. A. (1958) - Organizations. New York: Wiley. 
Morris, J., \& Sherman, J.D. (1981). Generalizability of an organizational commitment model. Academy of Management Journal, 24, 512-526.

Morrow, P. (1983). Concept redundency in organizational research: The case of work commitment. Academy of Management Review, $\underline{8}$, 486-500.

Mortensen, C. D., Arnston, P. H., \& Lustig, N. W. (1977). The measurement of verbal predispositions: Scale development and application. Human communication Research, $\underline{3}, 146-158$.

Mowday, R. T., \& Steers, R. M., \& Porter, L. W. (1979) . The measurement of organizational commitment. Journal of Vocational Behavior, 14, 224-247.

Mowday, R. T., Porter, L. W. \& Steers, R. M. (1987). Employee-organization linkages: The psychology of commitment, absenteeism, and turnover. New York: Academic Press.

Naisbitt, J. \& Aburdene, P. (1985) . Re-inventing the Corporation. New York: Warner Books Edition.

Pascarella, E. T., Duby, P. B., \& Iverson, B. K. (1983) . A test and reconceptualization of a theoretical model of college withdrawal in a commuter institution setting. sociology of Education, 56, 88-100.

Pascarella, E.T., Duby, P. B., Miller, V. A., \& Rasher, S. P. (1981). Preenrollment variables and academic performance as predictors of freshman year persistence, early withdrawal, and stopout behavior in an urban, nonresidential university. Research in Higher Education, 15, 329-349.

Patchen, M. (1970). Participation, achievement, and involvement on the job. Englewood cliffs, NJ: PrenticeHall.

Petty, R. E. \& Cacioppo, J. T. (1989). Attitudes and Persuasion.

Pfeffer, J. (1981) - Power in organizations. Marshfield, MA: Pitman.

Porter, L. W., \& Steers, R. M. (1973) . Organizational, work, and personal factors in employee turnover and

absenteeism. Psychological Bulletin, 80, 151-176. 
Porter, L. W., Lawler, E. E., \& Hackman, J. R. (1975) . Behavior in organizations. New York: McGraw-Hill.

Porter, L. W. , steers, R. M., Mowday, R. T., \& Boulian, P. v. (1974). Organizational commitment, job satisfaction, and turnover among psychiatric technicians. Journal of Applied Psychology, 59, 603-609.

Price, J. L. (1977). The study of turnover. Ames: Iowa State University Press.

Reichers, A. E., (1985). A review and reconceptualization of organizational commitment. Academy of Management Review, 10, 465-476.

Schein, E. H. (1968). Organization Socialization and the profession of management. Industrial Management Review, 9, 1-16.

Schein, E. H. (1971). The individual, the organization, and the career: A conceptual scheme. Journal of Applied Behavioral Management, I, 401-426.

Simon. H. (1976) . (3rd Ed.) . Administrative behavior:

A study of decision-making process in administrative organizations. New York: Academic Press.

Spady, w. (1970). Dropouts from higher education: An interdisciplinary review and synthesis. Interchange, 1 , 258-270.

Steers, R. M. (1977). Antecedents and outcomes of organizational commitment. Administrative Science Quarterly, 22, 46-56.

Steers, R. M., \& Mowday, R. (1981). Employee turnover and postdecision accommodation processes. In $\mathrm{L}$. Cummings and B. Staw (Eds.), Research in organizational behavior, 3, Greenwich, CT: JAI Press.

Terenzini, P.T., Lorang, W. G., \& Pascarella, E. T. (1981). Predicting freshman persistence and voluntary dropout decisions: A replication. Research in Higher Education, 2, 109-127.

Thibaut, J. W. \& Kelley, H. H. (1959). The social psychology of groups. New York: Wiley.

Tinto, V. (1975). Dropout from higher education: A theoretical synthesis of recent research. Review of Educational Research, 45, 89-125. 
Tinto, V. (1982). Limits of theory and practice in student attrition. Journal of Higher Education, 53, 687-700.

Tinto, V. (1987). Leaving college: Rethinking the causes and cures of student attrition. The University of Chicago Press: Chicago \& London.

Tinto, V. \& Lentz, B. (1986). Rates of system departure from higher education: 1890-1980. Paper presented to the annual meeting of the American Educational Research Association, San Francisco.

Tompkins, P. K., \& Cheney, G. (1985). Communication and unobtrusive control in contemporary organizations. In R. D. McPhee \& P. K. Tomkins (Eds.), organizational communication: Traditional themes and new directions (pp. 179-210) . Newbury Park, CA: Sage.

Van Gennep, A. (1960). The rites of passage. Translated by M. Vizedon and G. Caffe. Chicago: University of Chicago Press. Originally purlished as les rites de passage. Paris: Nourry, 1909.

Van Maanen, J. (1975) . Breaking in: Socialization to work. In R. Dubin (Ed.), Handbook of work, organization and society (pp. 67-120). Chicago: Rand McNally.

Van Maanen, J. \& Schein, E. H. (1979) Toward a theory of organizational socialization. In B. Staw \& L. L. Cummings (Eds.) Greenwich, Conn: JAI Press.

Wanous, J. P. (1977) . Organizational entry: Newcomers moving from outside to inside. Psychological Bulletin, 84, 601-618.

Wanous, J. (1980) - Organizational entry: Recruitment, selection, and socialization of newcomers. Reading, MA: Addison-Wesley.

Wehrenberg, S. B. (1989). Skill and motivation divide training and orientation. Personnel Journal, May. 
APPENDIX A

CONSENT FORM 
I, hereby agree to serve as a subject in the research project entitled "Student Commitment to Portland state University" conducted by Suzanne Pastori under the supervision of David Ritchie, $\mathrm{Ph} . \mathrm{D}$.

I understand that the study involves completing a questionnaire survey distributed by Suzanne Pastori.

It has been explained to me that the purpose of the study is to learn about the attitudes Portland state University students have about Portland state University.

I may not receive any direct benefit from participation in this study, but my participation may help to increase knowledge which may benefit others in the future.

Suzanne Pastori has offered to answer any questions I may have about the study and what is expected of me in the study. I have been assured that my identity will be protected in any discussion of results or in any written research summary.

I understand that I am free to withdraw from participation in this study at any time without jeopardizing my course grade, persons who may have referred me to this study, my relationship with Suzanne Pastori, or Portland State University.

I have read and understand the foregoing information.

Date:

Signature:

If you experience problems that are the result of your participation in this study, please contact the chair of the Human Subjects Research Review Committee, office of Graduate Studies, 303 Cramer Hall, Portland State University, 503/725-5262. 
APPENDIX B

QUESTIONNAIRE 
Demographic Information

1. My sex is [ ] Male(1); [ ] Female(2).

2. I am years old.

3. My marital status is:
[ ] single(1);
[ ] Married (2);
[ ] Divorced (3);
[ ] Other (4):

4. My ethnic background (Please check appropriate box)

[ ] White, Non-Hispanic(1)

[ ] Black, Non-Hispanic(2)

[ ] Hispanic (3)

[ ] American Indian or Alaska Native(4)

[ ] Asian or Pacific Islander(5)

[ ] Other) 6):

5. Are you handicapped? (Please check appropriate box(s)

[ ] No(2)

[ ] Blind/visually impaired(3)

[ ] Deaf/hearing impaired (4)

[ ] Physically handicapped(5)

[ ] Other (6):(Explain)

6. What is your major?

7. Circle how long you have attended this college or univ. QUARTERS / TERMS

$\begin{array}{llllllllll}1 & 2 & 3 & 4 & 5 & 6 & 7 & 8 & 9 & 10+\end{array}$

8. I am a full time student. [ ] yes(1); [ ] no(2) 
9. My academic status is:

[ ] I am an undergraduate student. (1)

[ ] I am a graduate student. (2)

[ ] I am enrolled in a Master's Program. (3)

[ ] I am enrolled in a Doctoral Program. (4)

[ ] I am not formally enrolled. (5)

10. Did you transfer to PSU from another college/university?

[ ] yes(1); [ ] no(2)

11. Has anyone else in your family attended PSU?

[ ] yes (1); [ ] no(2)

12. Has anyone else in your family graduated from PSU?

[ ] yes (1); [ ] no(2)

13. Did you apply to other colleges/universities?

[ ] yes (1); [ ] no(2)

14. Why did you decide to enroll at PSU?

15. My very first encounter with PSU was

Very unsatisfactory

45

Very ${ }_{6}$ satisfactory

16. My very first encounter with PSU was:

[ ] Telephone contact(1) [ ] Mail(2)

[ ] In Person(3)

[ ] Other (4): 
17. MY present experience with PSU is:

very unsatisfactory

$12 \quad 3$

$4 \quad 5 \quad$ Very satisfactory

18. Before I decided to enroll at PSU, I learned about PSU from: (Check as many as apply)

[ ] Newspaper ad(1) [ ] Newspaper article(6)

[ ] Television(2) [ ] Radio(7)

[ ] Brochure(3) [ ] Informational Fair(8)

[ ] Teacher(4) [ ] Friend(9)

[ ] Relative(5)

[ ] Other(10):

19. Do you intend to return to PSU to take additional classes?

[ ] yes(1); [ ] no(2); [ ] maybe(3)

20. Please explain your reasons for either planning to return or planning not to return:

21. Compared with other colleges and universities in the region, do you believe PSU is:

Much worse

Average

Much better

$\begin{array}{lllllll}1 & 2 & 3 & 4 & 5 & 6 & 7\end{array}$

22. Do you believe other people rate PSU as:

Poor

1

2

3

Average

4

5

Excellent

6 
Listed below are a series of statements that represent possible feelings that individuals might have about college/university in which they are enrolled. With respect to your own feelings about Portland state University (PSU), please indicate the degree of your agreement or disagreement with each statement by circling one of the seven alternatives below each statement:

The alternative responses are:

YES! : I agree very strongly with the statement.

YES : I agree strongly with the statement.

yes : I agree with the statement.

? : I neither agree nor disagree with the statement.

no : I disagree with the statement.

No : I disagree strongly with the statement.

No! : I disagree very strongly with the statement.

1. I am willing to put in extra effort to help PSU be successful.

NO! NO no ? Yes YES

2. I tell my friends this is a great university to attend. NO! No no ? Yes YES YES!

3. I feel very loyal to PSU.

NO! NO no ? Yes Y YES!

4. MY values are similar to PSU's values.

No! No no ? Yes YES

5. I am proud to tell others that I am part of PSU.

NO! NO no ? Yes YES!

6. I could just as well be educated in a different college/university.

NO! NO no ? Yes


7. PSU inspires my very best performance.

No! No no ? yes YES YES!

8. It would be easy for me to leave PSU.

NO! NO no ? Yes YES YES!

9. I am glad I chose PSU over all others.

NO! NO no ? Yes YES

10. There's little to be gained by staying with PSU.

NO! NO no ? yes YES YES!

11. I find it easy to agree with PSU's policies (e.g. Student Handbook/Bulletin).

NO! NO no ? Yes YES

12. I really care about the fate of PSU.

NO! NO no ? yes YES YES!

13. This is the best of all possible colleges/universities I could have attended.

NO! NO no ? Yes YES

14. Deciding to enroll at PSU was a mistake. (R)

NO! NO no ? yes YES

15. Attending PSU is satisfying.

NO! NO no ? yes YES

16. I feel that I socially belong at PSU.

NO! NO no ? yes YES

17. I feel that I have adequate opportunity at PSU to hear speakers to whom I can relate.

No! NO no ? yes YES

18. I feel that I am treated fairly in my classes at PSU.

No! No no ? yes YES 
19. I feel that my PSU instructors are sensitive to me.

NO! NO no ? yes YES

20. I feel that the curriculum at PSU adequately reflects cultural diversity.

NO! No no ? yes YES

21. I feel that the PSU faculty treats minority students fairly.

NO! NO no ? yes YES

22. I would rate the teaching caliber of my instructors as satisfactory.

NO! NO no ? yes YES

23. I would rate the quality of the other PSU personnel (e.g. registration, cashiers, degree requirements department, financial aid, secretaries, administrators, etc.) as satisfactory.

NO! No no ? yes YES

24. The organization, expertise, and teaching ability of my instructors are important to my commitment to remain at PSU.

NO! NO no ? yes YES

25. I have had the opportunity to interact with people from diverse cultures.

NO! NO no ? yes YES

26. Interaction with people from diverse cultures is important to me.

NO! NO no ? yes YES

27. What is the chance that $y$ ou will remain with PSU until you receive your degree? Write ina number between $0 \%$ and $100 \%$ to indicate the chance you will remain here.

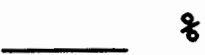

28. What does it take to do well as a PSU student? 
29. What attitudes/values are most rewarded by PSU instructors?

30. How have your attitudes and values changed since you began your education here?

31. What ONE person at PSU has had the greatest influence on you?

[ ] Professor (1)

[ ] Administrator(2)

[ ] student (3)

[ ] Other(4)

32. How has this person influenced you? 


\section{APPENDIX C}

\section{RESPONSE AVERAGES FROM 355 SURVEYS (H1)}

AND

TERM 1 - TERM 2 - TERM 3 (H2) 


\begin{tabular}{|c|c|c|c|c|}
\hline Variable & $\begin{array}{c}\text { Term } \\
1\end{array}$ & $\begin{array}{c}\text { Term } \\
2\end{array}$ & $\begin{array}{c}\text { Term } \\
3\end{array}$ & $\begin{array}{c}\text { Frequency } \\
\text { and } \% \text { of } \\
355 \\
\text { Students }\end{array}$ \\
\hline $\begin{array}{l}\text { Satisfaction } \\
\text { Increase } \\
\text { Decrease } \\
\text { Unchanged Overall } \\
(1-4) \text { Low } \\
(5-7) \text { High } \\
\text { Missing } \\
\text { Total \# of Subjects }\end{array}$ & $\begin{array}{l}52.2 \% \\
21 \cdot 7 \% \\
21.1 \% \\
17.1 \% \\
4.3 \% \\
1 \\
23\end{array}$ & $\begin{array}{l}36.08 \\
20.08 \\
44.08 \\
28.08 \\
16.08 \\
0 \\
25\end{array}$ & $\begin{array}{l}33.3 \% \\
27.2 \% \\
39.5 \% \\
22.2 \% \\
17.3 \% \\
0 \\
81\end{array}$ & $\begin{array}{rl}116 & 32.7 \% \\
118 & 33.2 \% \\
115 & 32.48 \\
76 & 21.48 \\
55 & 15.5 \% \\
6 \\
355\end{array}$ \\
\hline $\begin{array}{l}\text { Personal Intention } \\
\text { Yes, I will return } \\
\text { No, I won't return } \\
\text { Unsure I'll return } \\
\text { Missing } \\
\text { Total \# of subjects }\end{array}$ & $\begin{array}{c}87.0 \% \\
19.0 \% \\
4.3 \% \\
0 \\
23\end{array}$ & $\begin{array}{l}48.0 \% \\
20.0 \% \\
32.0 \% \\
0 \\
25\end{array}$ & $\begin{array}{l}69.1 \% \\
11.1 \% \\
19.8 \% \\
0 \\
81\end{array}$ & $\begin{array}{cc}235 & 66.2 \% \\
53 & 15.1 \% \\
94 & 26.5 \% \\
3 \\
355\end{array}$ \\
\hline $\begin{array}{l}\text { Personal Commitment } \\
100-80 \% \text { sure } \\
60-70 \% \text { sure } \\
40-59 \% \text { sure } \\
20-39 \% \text { sure } \\
0-19 \% \text { sure } \\
\text { Missing } \\
\text { Total \# of subjects }\end{array}$ & $\begin{array}{c}74.08 \\
8.7 \% \\
8.7 \% \\
0 \\
0 \\
0 \\
23\end{array}$ & $\begin{array}{c}76.0 \% \\
12.0 \% \\
0 \\
0 \\
12.0 \% \\
0 \\
25\end{array}$ & $\begin{array}{l}75.3 \% \\
7.4 \% \\
6.2 \% \\
2.5 \% \\
81\end{array}$ & $\begin{array}{rl}253 & 72.3 \% \\
21 & 6.0 \% \\
17 & 4.8 \% \\
11 & 2.9 \% \\
11 & 2.9 \% \\
& 22 \\
355\end{array}$ \\
\hline $\begin{array}{l}\text { Socialization } \\
\text { Professor } \\
\text { Administrator } \\
\text { Peer (student) } \\
\text { Other } \\
\text { Missing } \\
\text { Total \# of subjects }\end{array}$ & $\begin{array}{c}43.5 \% \\
4.3 \% \\
26.1 \% \\
13.0 \% \\
3 \\
23\end{array}$ & $\begin{array}{l}48.0 \% \\
0 \\
28.0 \% \\
16.0 \% \\
2 \\
25\end{array}$ & $\begin{array}{c}32.1 \% \\
6.2 \% \\
33.3 \% \\
17.3 \% \\
9 \\
81\end{array}$ & $\begin{array}{rl}170 & 48.6 \% \\
21 & 6.0 \% \\
81 & 23.1 \% \\
57 & 16.3 \% \\
& 26 \\
& 355\end{array}$ \\
\hline
\end{tabular}

